\title{
ANÁLISIS ECONÓMICO DEL DERECHO PENAL Y DERECHO PENAL LIBERAL: CONFLUENCIAS Y BIFURCACIONES*
}

Diego H. Goldman **

Resumen: No todo análisis económico lleva necesariamente a un Derecho penal maximalista que amenaza los derechos fundamentales de los individuos, sino que, por el contrario, es posible encontrar en la ciencia económica enfoques perfectamente compatibles con las corrientes más liberales del pensamiento penal.

Este trabajo se propone hacer un estudio crítico de la teoría económica usualmente asociada al AED Penal, de sus implicancias prácticas y sus presupuestos teleológicos. La crítica partirá de una mirada abiertamente liberal, que defiende las ideas y valores que a lo largo de los siglos han expresado pensadores tan diversos como Adam Smith, Friedrich Von Hayek, Robert Nozick o Juan Bautista Alberdi.

* El presente trabajo fue presentado como ponencia en las XXXVII Jornadas Internacionales de Derecho Penal y Criminología de la Universidad Externado de Colombia. Bogotá D.C., agosto de 2015.

** Abogado. Egresado de la Facultad de Derecho, de la Universidad de Buenos Aires. Magíster en Economía y Ciencias Políticas de la Escuela Superior de Economía y Administración de Empresas (ESEADE). Actualmente se desempeña como Subsecretario de Asuntos Jurídicos del Ministerio de Seguridad de la República Argentina. Buenos Aires, Argentina. Correo-e: goldman.diego@gmail. com. Fecha de recepción: 17 de marzo de 2017. Fecha de modificación: 26 de mayo de 2017. Fecha de aceptación: 31 de agosto de 2017. Para citar el artículo: DiEGo H. GOLDMAN. “Análisis económico del Derecho penal y Derecho penal liberal: confluencias y bifurcaciones”, en Revista Derecho Penal y Criminología, Vol. 38, n. ${ }^{\circ}$ 104, enero-junio de 2017, Bogotá, Universidad Externado de Colombia, pp. 13-74. DOI: https://doi.org/10.18601/01210483.v38n104.02 
Palabras clave: Análisis Económico del Derecho, AED, Derecho penal liberal, Escuela clásica, Derecho penal liberal, Maximalismo penal.

\title{
ECONOMIC ANALYSIS OF CRIMINAL LAW AND LIBERAL CRIMINAL LAW: CONFLUENCES AND FORKS
}

\begin{abstract}
Not all economic analysis necessarily lead to a maximalist criminal law that threatens the fundamental rights, but on the contrary, can be found in economic science approaches perfectly compatible with the most liberal thought currents. This paper aims to make a critical study of economic theory usually associated with the Criminal EAL, its practical implications and its teleological budgets. Criticism will leave an openly liberal view, which defends the ideas and values that over the centuries have expressed such diverse thinkers as Adam Smith, Friedrich von Hayek, Robert Nozick or Juan Bautista Alberdi.
\end{abstract}

Keywords: Economic Analysis of Law, liberal criminal law, Economic Analysis of Criminal Law.

\section{INTRODUCCIÓN}

El Análisis Económico del Derecho (AED) no es otra cosa que la disciplina que recurre al empleo de las herramientas de la ciencia económica para el estudio del sistema jurídico, con el propósito de determinar los efectos prácticos de normas legales y resoluciones judiciales y, eventualmente, promover reformas en aras de alcanzar de modo más eficiente los objetivos que aquellas persiguen.

Si bien este enfoque obtuvo en el mundo sus credenciales académicas a comienzos de la década de 1960 con los trabajos de Ronald Coase y Guido Calabresi sobre el Derecho de daños, no resulta aventurado afirmar que ciertas preocupaciones sobre los efectos "económicos" de las normas han estado presentes durante siglos en el razonamiento de los juristas, particularmente en la tradición jurídica anglosajona.

En el ámbito del Derecho penal, pueden incluso encontrarse atisbos del razonamiento económico en la obra fundamental del Derecho penal liberal moderno, el famoso De los delitos y las penas, del marqués de Beccaria. El ilustre jurista italiano mostraba ya un incipiente interés en la búsqueda de la eficiencia del sistema penal, al sostener que dado que el fin de las penas no es otro que la prevención del delito, "[s]e deben elegir, entonces, esas penas, y ese método para infligirlas, que, mantenida la proporción, causen una impresión más eficaz y duradera en el ánimo de los hombres, y la menos tormentosa en el cuerpo del reo"l.

1 Cesare Beccaria. De los delitos y de las penas. Antonio Bonanno (trad.), Buenos Aires, Losada, 2004 , p. 48 
Algunos años más tarde sería Jeremy Bentham quien efectuaría un estudio algo más sistemático de la cuestión. Su análisis partía de considerar al delincuente como una persona que trata de maximizar racionalmente los beneficios de sus acciones, llegando de tal modo a la conclusión de que el problema básico del control penal se reducía a determinar los "precios" adecuados para disuadir el crimen, mediante la cuidadosa manipulación de la severidad y probabilidad de imposición de las penas ${ }^{2}$. Esta sería la idea que retomaría Gary Becker en su famoso trabajo del año 1968, Crime and punishment: an economic approach, primer intento de analizar sistemáticamente la cuestión penal desde un enfoque económico, y que dio inicio al AED penal como disciplina autónoma. La lejana influencia de Bentham quizás tenga también algo que ver con el marcado cariz utilitarista que caracteriza a buena parte de la producción teórica en la materia.

Ese enfoque utilitarista tan propio del pensamiento jurídico anglosajón es, en mi opinión, una de las razones que ha conspirado contra la difusión del AED penal en los ámbitos académicos latinoamericanos. Imbuidos de cierto espíritu idealista característico de la tradición latina -habitualmente más preocupada por los fines enunciados por las normas que por sus resultados concretos- el análisis económico se nos aparece como una herramienta que deshumaniza el Derecho penal y lo convierte en una mera matemática de la violencia, que lleva implícita además una lógica difícil de compatibilizar con el respeto a los derechos humanos y los principios clásicos del Derecho Penal Liberal.

Desde mi punto de vista, si bien es cierto que en ocasiones el análisis económico puede llevar a conclusiones que colisionan con principios jurídicos arraigados en nuestras tradiciones e, incluso, con nuestra sensibilidad moral, no debemos caer en el error de abandonar una herramienta útil por el mal uso que puede dársele. Por otro lado, tampoco debemos olvidar que las herramientas que brinda el pensamiento económico son en sí mismas perfectibles, y a veces lo que falla no es la idea de utilizar la economía para analizar el Derecho, sino la particular teoría económica que se aplica a ese análisis. Más adelante veremos que no todo análisis económico lleva necesariamente a un Derecho penal maximalista que amenaza los derechos fundamentales de los individuos, sino que, por el contrario, es posible encontrar en la ciencia económica enfoques perfectamente compatibles con las corrientes más liberales del pensamiento penal.

Lo que me propongo en este trabajo es, precisamente, un estudio crítico de la teoría económica usualmente asociada al AED penal, de sus implicancias prácticas y sus presupuestos teleológicos. No es, por cierto, empresa que no se haya intentado previamente. La diferencia sustancial en este caso radica en que no pretendo encarar la

2 Andrés RoEmer. Introducción al Análisis Económico del Derecho, México D.F., Fondo de Cultura Económica, 1994, p. 7. 
faena desde una postura crítica de la teoría económica en general, o desde un moralismo de raíces religiosas, sino que la crítica partirá de una mirada abiertamente liberal, que defiende las ideas y valores que a lo largo de los siglos han expresado pensadores tan diversos como Adam Smith, Friedrich Von Hayek, Robert Nozick o Juan Bautista Alberdi.

Planteados el punto de partida y objetivos del trabajo, quedaría referirme brevemente a los temas puntuales que abarcará el análisis.

En primer lugar, analizaré cuestiones teóricas tales como la noción de acción humana que presupone la visión predominante del AED penal, la idea de "costo social" que lleva implícita y la posibilidad de su mensura, la influencia del concepto de "equilibrio de mercado" sobre sus propuestas de política criminal, etc.

Más adelante, y dado que el AED no se limita a una mera herramienta analítica, sino que suele estar acompañado de recomendaciones prescriptivas en materia procesal y de política criminal, dedicaré algunas páginas a valorar esas propuestas, tratando de determinar si resultan conciliables con los principios morales elementales del liberalismo, así como con las garantías fundamentales del Derecho penal moderno.

Finalmente, me abocaré a esbozar algunas propuestas normativas que tienden a conciliar el análisis económico con una visión minimalista del Derecho penal. Para ello, partiré de los postulados teóricos de la Escuela Austríaca de Economía, apartándome de la visión neoclásica que predominantemente tiñe al AED. Estas líneas de acción, en lo fundamental, tienden a una reducción significativa del ámbito de lo punible, apelando a formas alternativas de resolución de conflictos y a la participación activa de la víctima en el proceso.

\section{RUDIMENTOS DE ANÁLISIS ECONÓMICO DEL DERECHO PENAL}

El análisis económico de las conductas delictivas y los mecanismos empleados para su prevención se basa en una idea tan simple como poderosa: que los delincuentes son personas racionales como el que más, y no actúan sino tratando de maximizar sus beneficios individuales.

Esta idea, que quizá hoy pueda parecernos una perogrullada, implicó en su momento una auténtica revolución en el pensamiento penal. Pensemos que, aun hoy, no es extraño que se caracterice al delincuente como un desviado moral, un ser antisocial o inclusive como un enfermo mental. Grande habrá sido, entonces, la perplejidad causada por Bentham dos siglos atrás, al enunciar que los reos eran simplemente personas que actuaban racionalmente en la creencia de que el delito era la actividad más redituable que podían emprender. De esta idea, además, se deducen una serie de axiomas que constituyen la estructura básica del AED penal. 
Estos axiomas, a su vez, buscan develar, al decir de Gary Becker, las respuestas a preguntas tales como cuántos recursos debería la sociedad emplear en reforzar el cumplimiento de sus leyes mediante la amenaza de la pena, qué tipos de ofensas deberían ser permitidas o cuántos delincuentes deberían quedar impunes para maximizar el beneficio social total ${ }^{3}$. El objetivo es alcanzar un sistema penal "eficiente" que minimice el costo social del delito, persiguiendo solo aquellas conductas que causan daños mayores al costo de su prevención, y graduando las penas de modo tal de alcanzar el máximo grado de disuasión al menor costo posible.

Pero, ¿cuáles son en definitiva esos axiomas que postula el análisis económico aplicado al Derecho penal?

La idea basal es que los individuos que delinquen actúan racionalmente con base en incentivos y en la expectativa de maximizar su beneficio personal: una persona llevará a cabo un hecho ilícito en la medida en que estime que sus beneficios potenciales resultarán superiores a los costos esperados. Así, por ejemplo, un potencial ladrón evaluará si el botín que espera obtener en un atraco es más valioso que el tiempo que eventualmente podría pasar en prisión si es descubierto por las autoridades. Si, subjetivamente, el valor de los bienes robados resulta mayor que la estimación de potenciales perjuicios, el delito se llevará a cabo. En caso contrario, el sujeto optará por dedicarse a otro tipo de actividad.

Partiendo de esta base, el AED penal postula que es posible disuadir a los potenciales delincuentes elevando el costo esperado de los actos ilícitos. Y, si bien se admite que la pena esperada no es lo único que el eventual ofensor tendrá en cuenta antes de cometer un delito, se sostiene que es posible reducir la criminalidad manipulando sus componentes, que son la probabilidad y magnitud de la sanción. En palabras de Becker:

Prácticamente todas las diversas teorías coinciden [...] en que cuando otras variables se mantienen constantes, un incremento en la probabilidad de que una persona reciba una condena, o del castigo si es condenada, generalmente disminuirá, quizás substancialmente, quizá insignificantemente, el número de delitos que aquella cometerá ${ }^{4}$.

En segundo lugar, el AED penal sostiene que es menester tener en cuenta los distintos costos sociales que genera el delito, entre los que se cuentan por un lado los daños causados a la víctima y al resto de la sociedad, y por el otro los costos derivados de la puesta en funcionamiento del aparato policial y judicial destinado a detectar y sancionar esos ilícitos.

3 Cfr. GARY BECKER. "Crime and punishment: an economic approach", Journal of Political Economy, Vol. 76, n. ${ }^{\circ}$ 2, Marzo/Abril 1968, Chicago, University of Chicago, 1968, p. 170.

4 Ibídem, p. 176. La traducción es propia. 
Dentro de los daños que genera un delito, es relativamente sencillo identificar aquellos irrogados directamente a la víctima: destrucción de sus bienes, privación de su libertad, lesiones corporales, etc. Algo más complicado es determinar cuál es el daño que un hecho ilícito ocasiona a individuos que no son ni la propia víctima ni sus allegados directos. Por lo general, se entiende que el delito genera en el resto de los miembros de la sociedad un sentimiento de temor que constituye un costo social o daño público de suficiente entidad para justificar la intervención estatal tendiente a su evitación. Sobre esta cuestión, nos detendremos más adelante.

Por otra parte, cabe tener en cuenta que la disuasión del delito también implica determinados gastos mensurables monetariamente, tales como sueldos para el personal policial y judicial, inversiones en infraestructura carcelaria, sistemas informáticos de monitoreo, etc. En términos generales, estos costos se incrementan proporcionalmente al aumento en la probabilidad de detección y enjuiciamiento de los delincuentes, así como de la severidad de las penas: para mejorar la probabilidad de atrapar a quienes han cometido delitos será necesario destinar fondos a aumentar la cantidad de policías en las calles, invertir en tecnología forense, capacitación del personal, etc.; a la vez que mantener a los condenados en las cárceles por un mayor lapso incrementará los gastos de alojamiento.

De lo hasta aquí expuesto, podemos extraer que el Derecho penal será eficiente en la medida en que el costo social de la disuasión de las conductas ilícitas tienda a igualarse con el monto total de los daños que las mismas provocan. Ello por cuanto, si los recursos invertidos en disuasión estuvieran por debajo del punto de igualación con el costo social del delito, todavía podría obtenerse un beneficio social marginal incrementando los niveles de disuasión. Por el contrario, por encima del hipotético "punto de equilibrio", el costo de la disuasión "excedente" deviene superior al beneficio social marginal de la reducción del delito obtenida, por lo que resultaría socialmente beneficioso dejar algunos delitos impunes ${ }^{5}$.

En los siguientes apartados analizaremos más detenidamente estos axiomas y algunas de las objeciones que merecen tanto a nivel metodológico como axiológico.

\section{UNA CRÍTICA METODOLÓGICA}

Desde el punto de vista de la economía, un delito es un daño no consentido, que debería o no ser tolerado por el sistema jurídico en la medida en que produzca un enriquecimiento o un empobrecimiento netos para el conjunto de la sociedad.

5 Cfr. Robert Cooter y Thomas Ulen. Derecho y economía. Eduardo Suárez (trad.), México D.F., Fondo de Cultura Económica, 1998, p. 564. 
Tengamos en cuenta, en este sentido, que no todo daño implica un verdadero empobrecimiento neto para la persona que lo sufre y el conjunto de la sociedad, o que existen situaciones en las cuales el perjuicio causado a la víctima es tan insignificante, que intentar evitarlo significaría imponer a la sociedad un costo mayor al valor de los bienes que se procura proteger. Dentro del primero de estos grupos, tenemos la clase de casos que el Derecho penal usualmente resuelve a través de institutos como el de la legítima defensa o el estado de necesidad-como el ejemplo del sujeto que rompe la puerta de la casa del vecino con un hacha, para salvar a su familia de un incendio-, donde el "daño" no consentido es necesario para evitar un costo social mayor, por lo que, en realidad, causan un enriquecimiento social neto. Por su parte, dentro del segundo grupo tenemos los casos generalmente descartados por el Derecho penal a través del principio de insignificancia o de la idea del delito de bagatela, como lo sería el supuesto en que una persona le arranca un pelo a otra. Partiendo de una perspectiva económica que busca maximizar la riqueza o bienestar de la sociedad todos estos casos, lógicamente, deberían quedar al margen de la tipificación penal.

El Derecho penal, entonces, debería ocuparse solo de aquellos casos que producen un empobrecimiento social neto, es decir un daño - a la víctima y a terceros- mayor al costo que hipotéticamente implicaría su prevención.

Ahora bien, para alcanzar este objetivo de maximización de la riqueza social que, para el AED, el Derecho penal debería perseguir, resulta necesario analizar cuidadosamente:

- Las causas que mueven a una persona a causar un daño no consentido a otra, y el modo en que esas conductas se pueden llegar a disuadir.

- El costo que esos daños no consentidos generan a la sociedad y la posibilidad de mensurarlo adecuadamente.

- Las posibilidades concretas de que el sistema penal pueda captar aquellas conductas que producirían un empobrecimiento social neto y hacer efectiva su prohibición al menor costo posible.

A continuación, trataré de analizar hasta qué punto son válidas las explicaciones que el AED penal ha dado usualmente a estas tres cuestiones.

\section{III.A. La acción racional mal entendida}

\section{III.A.1. Las limitaciones del modelo del Homo Economicus}

Como punto de partida para analizar el problema del delito, la ciencia económica necesita explicar por qué algunas personas deciden violar las normas jurídicas y otras no. El rasgo característico del análisis económico, como ya hemos visto, consiste en desechar las explicaciones psicológicas, biológicas o sociológicas y asumir que la persona que delinque actúa racionalmente intentando maximizar su beneficio personal. 
Ahora bien, ¿qué entiende el análisis económico por “acción racional”?

Según Gary Becker, en relación a este punto, el análisis económico del Derecho penal:

... sigue el análisis de la elección que hacen usualmente los economistas y asume que una persona comete una ofensa si su utilidad esperada excede la utilidad que podría obtener empleando su tiempo y otros recursos en otras actividades. Algunas personas devienen "criminales", entonces, no porque sus motivaciones básicas difieran de las de otras personas, sino porque sus costos y beneficios son diferentes ${ }^{6}$.

El primer problema que enfrenta el análisis económico consiste, entonces, en determinar cuáles son los costos y beneficios que evalúa el individuo para decidir si llevará a cabo una acción determinada. Por lo general se recurre a un modelo simplificado de conducta humana, en el que no entran en consideración las motivaciones de carácter ético o moral. Así vemos que:

... la teoría económica del crimen y el delito se construye bajo el supuesto del "criminal racional amoral". Se trata, en este caso, de una persona que carece de principios morales que guíen sus acciones pero que es racional, en el sentido que evalúa las alternativas a las que se enfrenta considerando sus ganancias (no necesariamente materiales) y los costos (también no necesariamente materiales o monetarios), eligiendo aquella alternativa que implique el más eficiente uso de los recursos ${ }^{7}$.

Además, para posibilitar la aplicación de herramientas matemáticas al análisis económico del delito, el modelo de "criminal racional" no solo presupone la ausencia de restricciones morales a la acción, sino también que las preferencias del individuo son estables a lo largo del tiempo y que este es neutral ante el riesgo.

Finalmente, y pese a reconocer la existencia de motivaciones "no materiales", el AED penal tiene por lo general un marcado sesgo al considerar los beneficios y pérdidas de carácter monetario como únicas variables relevantes que determinan la acción del individuo, descartando otro tipo de motivaciones, tales como el deseo de agradar a los pares, la venganza, el miedo, etc.

Así, según la hipótesis de trabajo del AED, un individuo considera como "ganancia" del delito los beneficios monetarios que espera obtener de él, en tanto que el "costo" estaría compuesto, por un lado, por los ingresos vinculados a actividades lícitas que

6 GARY BeCKer. Ob. cit., p. 176.

7 Marco Antonio del Río. "Nuevos rumbos de la criminología”, Laissez - Faire, n. 15, septiembre 2001, Guatemala, Universidad Francisco Marroquín, 2001, pp. 34-35. 
se dejan de percibir al emplear el tiempo en planificar y ejecutar el acto ilícito y, por el otro, por el monto de la pena esperada, esto es la magnitud de la pena establecida por el ordenamiento jurídico para la clase de delito en cuestión, multiplicada por la posibilidad de ser aprehendido y condenado. La pena esperada, por su parte, puede ser también expresada en términos monetarios, directamente en el caso de las multas, e indirectamente en el caso de la pena de prisión, en cuyo caso puede ser entendida como la suma de los ingresos dejados de percibir como consecuencia del encarcelamiento y el valor otorgado por la persona a las restricciones que se imponen a su libertad ${ }^{8}$.

Partiendo de estas premisas, puede concluirse que tanto un aumento de los ingresos que puedan obtenerse a través de actividades legales como un incremento de la pena esperada por el potencial delincuente, ya sea por una mayor severidad del castigo o por una mejora en los índices de detección y condena, tendrán como consecuencia un incremento en el "costo" del delito, y por tanto determinarán una reducción de la criminalidad ${ }^{9}$.

Esta concepción "económica" (o "economicista") de la acción humana ha calado tan hondo que, partiendo de ella explícita o implícitamente ${ }^{10}$, escuelas tan disímiles del pensamiento penal como el AED, que abreva en la teoría económica neoclásica, y la criminología crítica, de origen marxista, pueden coincidir no solo en que es posible establecer, con carácter general, que el delito tiene su origen en cuestiones económicas, sino que el poder público es capaz de disuadirlo eficazmente. En última instancia, las diferencias no parecen estar sino en la preponderancia que se les otorga a los distintos componentes del "costo" del delito: mientras para unos es fundamental la percepción de la pena esperada, para los otros lo es el nivel de ingresos que podría obtenerse en el mercado de trabajo legal.

Analicemos, sin embargo, estas creencias tan arraigadas respecto al modo como las variaciones en el "costo" del delito influyen sobre los índices de criminalidad.

En primer lugar, la idea de que existe una correlación entre las privaciones económicas -ya sea que adquieran la forma de miseria, desempleo o exclusión- y el delito, no por encontrarse sumamente extendida en nuestro ámbito académico deja de

8 Cfr. Gary Becker. Ob. cit., p. 179.

9 Cfr. ERLING EIDE; "Economics of criminal behavior", en AA.VV., Encyclopedia of Law and Economics. Volume V. The Economics of Crime and Litigation. Boudewijn BoucKaERT, Gerrit De GeEST (eds.), Cheltenham, Edward Elgar, 2000, p. 350.

10 Por lo general, los desarrollos de la criminología de raigambre marxista no reconocen explícitamente la adopción de un modelo de conducta racional basado en la premisa neoclásica del homo economicus. Sin embargo, las conclusiones a las que arriban en el sentido de que las principales causas de la criminalidad son la pobreza y la desigualdad social supuestamente generadas por el capitalismo resultan, paradójicamente, perfectamente compatibles con tal modelo. 
ser cuestionable. Al menos, como explicación del fenómeno de la criminalidad de alcance general, aun cuando pueda resultar plausible en algunos casos particulares.

En concreto, se ha apuntado que este tipo de explicaciones economicistas dejan sin resolver algunas situaciones dejadas al descubierto por estudios empíricos, que contradicen la hipótesis de que las privaciones materiales conducen al delito.

Así, dos autores de formación marxista, como Lea y Young, han observado que "[q]uizá el número de delitos cometidos por los pobres sea un reflejo de su situación económica, pero, incluso en este caso, el grado de pobreza no tiene relación con la tasa de criminalidad" 11 , apoyando sus conclusiones en estudios estadísticos comparativos realizados en los Estados Unidos en la década de 1970, en los que se analizaron dos grupos sociales igualmente afectados por la marginalidad como lo eran los individuos de raza negra y los de origen latinoamericano, observándose que el índice de detenciones era significativamente mayor entre los primeros ${ }^{12}$. Dichos autores ofrecen similares reparos a la correlación mecánica entre delito y desempleo, objetando:

La idea de que el desempleo conduce al delito se contrapone a la existencia de grupos de personas desempleadas con índices de criminalidad muy bajos. El sector más numeroso y obvio es el de las personas mayores, que tienen índices de criminalidad consistentemente más bajos que los de los jóvenes. Y por más válido que pueda ser el argumento de que la discreción por parte de la policía y de los tribunales tiende a reducir las cifras reales, existen pocas dudas de que las ancianas, por ejemplo, son delincuentes mínimos en comparación con los hombres jóvenes. El bajo índice de delincuencia de los ancianos, confirma además, incidentalmente, nuestro argumento de que no existe relación directa entre la pobreza y el delito... Al menos, como explicación del fenómeno de la criminalidad de alcance general, aun cuando pueda resultar plausible en algunos casos particulares. ${ }^{13}$.

Por su parte, la tesis del delincuente como maximizador racional amoral no sale mejor parada cuando la variable que se analiza no es ya el costo de oportunidad del acto delictivo en relación a actividades legales, sino los cambios en las penas esperadas.

En particular, se ha objetado la idea de que la pena esperada es la variable de mayor peso relativo entre aquellas que evaluaría un individuo a la hora de decidir si comete o no un delito, señalándose que ello implica adoptar una visión demasiado estrecha

11 John Lea y Jock Young. ¿Qué hacer con la ley y el orden? Martha Gil y Mariano Ciafardini (trads.), Buenos Aires, Del Puerto, 2001, p. 115.

12 Cfr. ibídem,pp. 115 y 116.

13 Ibídem, p. 118. 
del concepto de racionalidad, reduciéndolo a la mera maximización de beneficios materiales y dejando de lado otro tipo de fines que una persona podría válidamente perseguir sin por ello dejar de actuar "racionalmente". En tal sentido, parece desacertado subestimar la existencia de motivaciones de carácter ético o moral en el accionar de los individuos. Coincido al respecto en que:

La realidad muestra [...] que un elevado número de personas dejan de realizar conductas definidas en sentido criminalizante por restricciones de índole ética -moral internalizada en el proceso de socialización- y no por la tipificación de tal conducta en la ley penal con una alta probabilidad de aprehensión. Es decir, nos parece -cuando menos-ingenuo pensar que un elevado porcentaje de la población dejemos de matar a nuestros progenitores o practicar un acto sexual no consentido porque el costo del delito supera la utilidad esperada del mismo. Más lógico pareciera afirmar que otro tipo de barreras - que nada tienen que ver con la conminación de una pena- operan como factores de disuasión, llamémosle 'interna', de tales conductas ${ }^{14}$.

Por su parte, así como no esclarece las razones por las cuales muchas personas no delinquen aun cuando podría resultarles económicamente provechoso, el modelo del maximizador racional amoral tampoco explica satisfactoriamente los casos de delitos pasionales o cometidos bajo estados de profunda alteración emocional. Quien mata por despecho o agrede a otro en medio de una violenta discusión no realiza la clase de cálculo racional que presupone el AED Penal neoclásico sino que, por el contrario, resulta momentáneamente incapaz de motivarse en la norma, señalándose que “...un individuo dentro de un modelo de estado emocional gravemente alterado no será objeto de disuasión, no obstante que el nivel de sanción sea elevado"15. La eficiencia económica reclamaría, entonces, la lisa y llana abolición de los delitos cometidos bajo estados emocionales intensos, lo cual no acontece en realidad sino con ciertas limitaciones ${ }^{16}$.

14 NicolÁs LAino. “Criminología actuarial y Law \& Economics. Una visión crítica de la Teoría Económica del Crimen”, Cuadernos de Derecho Penal, Vol. 4, Neuquén, Colegio de Abogados y Procuradores de Neuquén. Instituto de Derecho Penal y Procesal Penal, 2007, p. 14.

15 Rubén Méndez Reategui. "Conducta delictiva, estados emocionales y disuasión: un enfoque económico”, Jus Doctrina y Práctica, n. ${ }^{\circ}$ 1, Lima, Editora Jurídica Girjley, 2008, p. 121.

16 La mayoría de las legislaciones penales contemplan la reducción o eximición de sanciones para estos casos. Así, por ejemplo, el Código Penal argentino exime de penas a quien hubiera actuado bajo una "alteración morbosa" de sus facultades mentales tal que le impida comprender la criminalidad de sus actos (art. 34), y contempla una pena reducida para el homicidio cometido en "estado de emoción violenta" (art. 81, inc. a). Soluciones similares establecen el art. 20.1 del Código Penal español, el art. 15.VII del mexicano, art. 33 del colombiano, etc. Sin embargo, en todos estos casos el fundamento para la disminución o exclusión de sanciones debe buscarse en la aplicación del principio constitucional de culpabilidad y no en consideraciones respecto de la eficiencia de la pena en términos económicos. 
Lo que me interesa recalcar, en definitiva, es que la existencia de delitos cometidos por motivaciones muy distintas a la maximización del beneficio material -que además no pueden ser disuadidos a través de la amenaza de la pena-desmiente categóricamente la hipótesis del homo economicus que adopta el AED neoclásico como explicación causal del delito.

\section{III.A.2. La evidencia empírica}

Una cuestión de suma importancia a la hora de valorar la capacidad explicativa de la teoría del delito postulada por el AED penal neoclásico, consiste en analizar la validación empírica de la hipótesis del maximizador racional amoral.

Al respecto cabe señalar que, si bien se ha estudiado bastante la correlación existente entre los niveles de delincuencia y los niveles de sanción esperada en distintas épocas y lugares, las conclusiones de este tipo de investigaciones no han resultado totalmente consistentes. Si bien, por lo general, un incremento en la probabilidad o severidad de las penas se refleja en una disminución de los índices de criminalidad, tal correlación no se verifica en la totalidad de los estudios realizados:

Debería recordarse, sin embargo, que en algunos estudios el efecto de un incremento en la severidad del castigo no es estadísticamente diferente a cero, y que también se ha encontrado ocasionalmente un efecto positivo con significancia estadística ${ }^{17}$.

Incluso algunos estudios sugerirían que, si se introducen en el análisis otras variables como las migraciones y la densidad poblacional, que tendrían a su vez incidencia sobre la probabilidad y severidad del castigo, el efecto de los cambios en las penas esperadas sobre los índices de delincuencia se torna estadísticamente irrelevante ${ }^{18}$.

La dificultad para establecer una correlación clara y consistente entre la evolución de los índices de criminalidad y las penas esperadas puede ilustrarse a través de algunos ejemplos que he tomado de las estadísticas criminales de distintos países europeos.

17 ERLING EIDE Ob. cit., p. 360.

18 Cfr. Brian Forst; "Participation in illegitimate activities: further empirical findings", Policy Analysis, Vol. 2, n. ${ }^{\circ}$ 3, Los Angeles, University of California Press, 1976, p. 477-492. Citado en ERLing EIDE. Ob. cit., p. 358 . 
Criminalidad vs. encarcelamiento - Italia 1990-2012

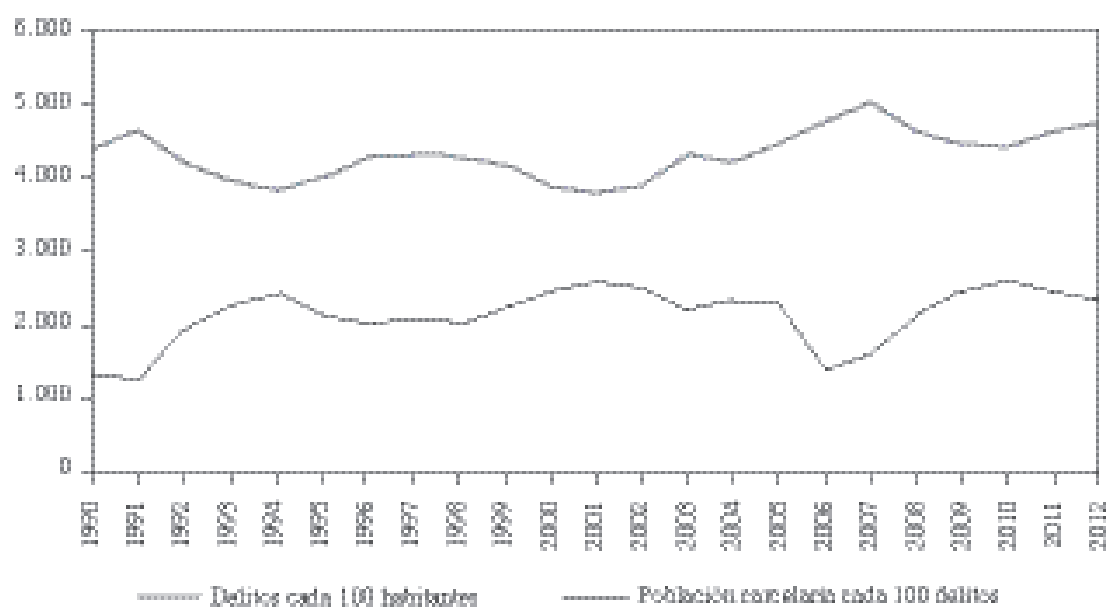

Fuente: Eurostat.

En el caso de Italia, he tomado la evolución de la tasa de delitos denunciados cada cien habitantes entre 1990 y 2012 y la he comparado con la cantidad de personas encarceladas por cada cien delitos denunciados en el mismo período, observándose una correlación casi exacta entre ambas variables, que parecería corroborar la hipótesis planteada por el AED.

Criminalidad vs. encarcelamiento - Holanda 1990-2012



Fuente: Eurostat. 
En el caso de Holanda, la correlación entre las variables ya no resulta tan clara. He tomado también la tasa de delitos por cada cien habitantes entre 1990 y 2012 y la proporción de personas privadas de la libertad durante idéntico período, en este caso cada mil delitos denunciados, para facilitar su visualización en el gráfico. Como puede observarse, solo entre los años 1995 y 2000, el comportamiento de las variables se adecúa a las predicciones del AED. Entre 1990 y 1994, la relación entre ambas tasas pareciera ser prácticamente opuesta a la que indicaría la hipótesis del AED -un incremento simultáneo de los delitos denunciados y el índice de encarcelamiento-, mientras que a partir del año 2000 se observa una lenta pero sostenida caída en el índice de delitos denunciados, que se independiza de las fluctuaciones de la tasa de personas encarceladas.

\section{Criminalidad vs. encarcelamiento - Holanda 1990-2012}

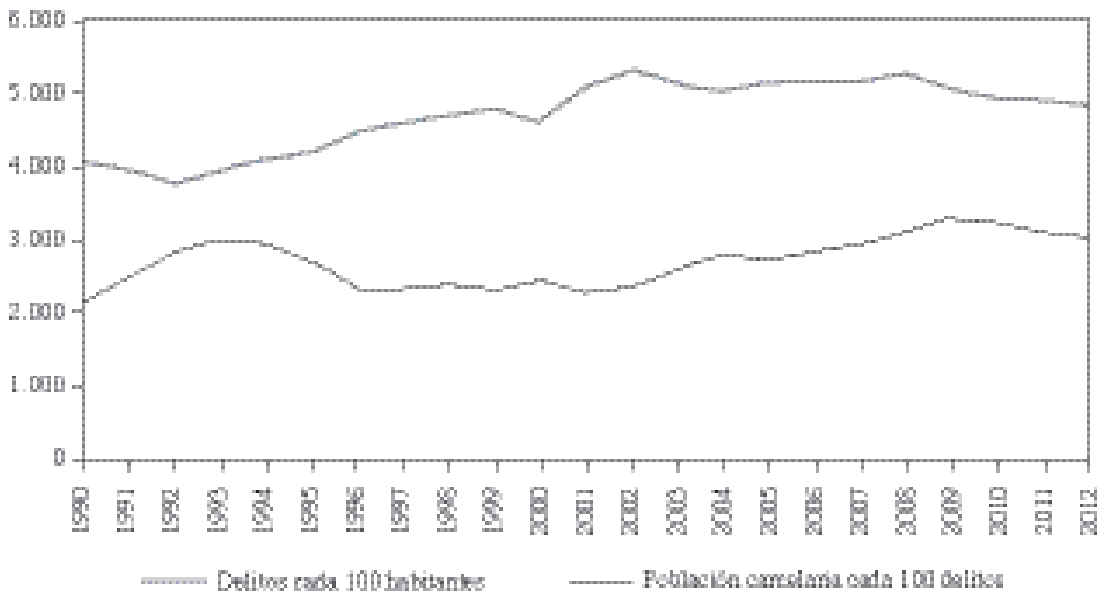

Fuente: Eurostat.

Finalmente, en el caso de España, tampoco resulta sencillo verificar la hipótesis planteada por el AED neoclásico, en el sentido de que la tasa de criminalidad será inversamente proporcional a la tasa de encarcelamiento. Tomando nuevamente las tasas de delitos denunciados por cada cien habitantes y de personas encarceladas por cada cien delitos, para el período 1990 a 2012, observamos que el comportamiento de las variables solo se adecúa a las predicciones del AED entre 1990 y 2000, en tanto que a partir de entonces pareciera observarse exactamente lo contrario: ambos índices van incrementándose de forma paralela aproximadamente hasta 2009, y a partir de ese año empiezan a caer también conjuntamente.

En definitiva, solo en el caso de Italia pareciera corroborarse la idea de que un incremento en la amenaza punitiva derivará en una caída de los índices de criminalidad y viceversa, en tanto que las estadísticas correspondientes a Holanda y España no permiten arribar con certeza a semejante conclusión. 
La disparidad en los resultados que pueden alcanzarse sometiendo la hipótesis del maximizador racional amoral frente a las estadísticas criminales de distintos países y épocas, pone en cuestión su capacidad explicativa y sus posibilidades de generalización.

Por otra parte, y aun en aquellos casos en los que las estadísticas parecen validar la hipótesis del AED penal neoclásico, no debemos olvidar que la correlación entre las variables analizadas no indica per se la relación de causalidad entre ellas. Así, cuando se encuentra una correlación negativa entre los índices delictivos y las tasas de condena, resulta difícil, cuando no imposible, establecer si una menor efectividad del sistema penal incrementa la delincuencia o si, por el contrario, es el aumento en la cantidad de delitos lo que lleva a una disminución de las posibilidades de castigo, al sobrecargar las tareas de la policía y los jueces, reduciendo de este modo su eficiencia ${ }^{19}$.

Finalmente, debemos considerar que las premisas desde las que el análisis neoclásico construye su hipótesis de trabajo (preferencias estables, neutralidad ante el riesgo, ausencia de motivaciones morales, etc.) condicionan por lo general los estudios empíricos destinados a verificarla, alterando el orden del razonamiento científico. Si los estudios econométricos se construyen excluyendo un significativo número de variables que podrían tener influencia en las inclinaciones delictivas de los individuos, y se limitan solo a analizar la relación entre los índices delictivos y las penas esperadas, es altamente probable que encuentren alguna vinculación entre esas variables, por más débil que sea. Pero, obrando de ese modo, la econometría pierde buena parte de su utilidad científica, convirtiéndose en un instrumento destinado más a justificar las premisas adoptadas que a someterlas a la posibilidad de refutación empírica.

Justo es decir que esta misma crítica puede efectuarse a cualquier otro enfoque que analice la criminalidad como un fenómeno unicausal. Resulta evidente, por el contrario, que los individuos actúan en base a motivaciones infinitamente diversas, y por ello resulta infructuoso elaborar una teoría económica del delito que pretenda explicar la totalidad del fenómeno de la criminalidad a partir de unas pocas variables.

¿Significa esto que la ciencia económica no tiene ningún rol útil que cumplir en el estudio del delito y el diseño de políticas criminales? Desde luego que no. Sin embargo, la economía, para arribar a conclusiones fructíferas, no requiere de ningún maximizador racional amoral fantasmagórico, y ni siquiera de obtusos modelos econométricos que, por más complejos y sofisticados que sean, jamás lograrán captar la infinita variedad de razones que llevan a los seres humanos a actuar.

En este sentido, me parece útil recurrir a los desarrollos de la Escuela Austríaca de Economía, la cual históricamente ha postulado que las ciencias sociales pueden

19 Cfr. ERLING EIDE. Ob. cit., p. 365. 
trabajar con una concepción menos acotada de la racionalidad humana, sin por ello resignar rigor científico. A ello me abocaré a continuación.

\section{III.B. La acción racional según la Escuela Austríaca}

La idea austríaca de la acción humana no resultará extraña a quienes se encuentran familiarizados con la dogmática penal, en tanto no difiere demasiado de lo postulado por la teoría finalista de la acción.

Todos los desarrollos de la denominada Escuela Austríaca, tanto en economía como en las restantes ciencias sociales, parten del análisis de las distintas implicancias del denominado "axioma" de la acción humana, según el cual los individuos actúan bajo la expectativa de que alcanzarán un estado de cosas más satisfactorio que aquel que existiría en ausencia de acción, es decir, persiguiendo una finalidad:

La acción humana se define simplemente como comportamiento deliberado. Por lo tanto, se diferencia claramente de aquellos movimientos observados que, desde el punto de vista del hombre, no son intencionales. Entre ellos se encuentran todos los movimientos observados en la materia inorgánica y ciertos tipos de comportamiento humano que son sólo actos reflejos, simples respuestas involuntarias a determinados estímulos. Por otra parte, los demás hombres pueden interpretar el sentido de la acción humana, ya que está regida por cierto propósito que el sujeto actuante tiene en mente. El propósito del actuar del hombre es su fin; el deseo de alcanzar ese fin es el motivo por el cual lleva a cabo la acción ${ }^{20}$.

Lo que distingue al enfoque austríaco de otras aproximaciones a la noción de acción humana es que rechaza que los individuos persigan o deban perseguir alguna clase de fin en particular. Según este enfoque, las finalidades pueden variar constantemente y por ello no es asunto de la economía -sino de la psicología u otras ciencias- establecer cuáles son los propósitos concretos que las personas persiguen con sus acciones. Tal como lo sostuviera Ludwig Von Mises, “[e]l contenido de la acción humana, es decir los fines a que se aspira y los medios elegidos y utilizados para alcanzarlos, depende de las particulares condiciones de cada uno"21.

Como vemos, se trata de una perspectiva radicalmente opuesta a la de la economía neoclásica, para la cual es válido, a los fines explicativos, postular que los indivi-

20 MurRay Rothbard. El hombre, la economía y el estado: un tratado sobre principios de economía. Norberto Sedaca (Trad.), Buenos Aires, ESEADE, 2004, p. 29.

21 LudWIG VON Mises. La acción humana, octava edición. JoAQuín REIG Albiol (trad.), Madrid, Unión Editorial, 2007, p. 55. 
duos tienen preferencias estables a lo largo del tiempo, las cuales pueden conocerse empíricamente y condensarse en datos agregados, útiles para analizar y establecer con precisión sus reacciones frente a determinados estímulos.

La racionalidad, desde la perspectiva austríaca, posee un carácter meramente instrumental, y no consiste en otra cosa que la disposición de los medios que cada individuo, con los elementos de juicio a su alcance, estime más adecuados para alcanzar determinado fin, cualquiera que este sea. No hay espacio, en la concepción austríaca de la acción humana, para ningún "maximizador racional amoral": la economía solo puede predicar que los individuos actúan persiguiendo fines, pero no puede establecer el contenido de esos fines, y mucho menos que este sea mensurable en dinero. Al respecto Mises, refiriéndose al homo economicus de la teoría neoclásica, sostenía:

Ese supuesto personaje jamás gozó de existencia real; es tan sólo un fantasma creado por arbitrarios filósofos de café. Nadie se guía exclusivamente por el deseo de enriquecerse al máximo; muchos ni siquiera experimentan esas apetencias materialistas. De nada sirve estudiar la vida y la historia ocupándose de tan fantasmal engendro ${ }^{22}$.

Resulta tan "racional”, en este sentido, quien roba un automóvil porque advierte que las ganancias que podría obtener de su venta superan con creces al costo esperado del delito, como quien, ante idénticas circunstancias, opta por no cometer el ilícito para cumplir con el mandato ético-religioso que impone "no robarás". La única diferencia entre ambos sujetos radica en la escala de valores a través de la cual ordenan sus fines.

Aceptar que las preferencias humanas varían no solo entre distintos individuos, sino que también pueden mutar significativamente para un mismo individuo a través del tiempo, implica derribar otro presupuesto epistemológico de la economía neoclásica: que las escalas de valores pueden determinarse a priori de las acciones individuales concretas. Las predicciones que el AED penal "tradicional" hace respecto de las reacciones que tendrán los potenciales delincuentes ante modificaciones en variables como la severidad de las penas o la eficiencia del accionar judicial, se basan precisamente en la idea de que las escalas de valores de los individuos pueden conocerse antes de que concreten acción alguna, y por ello puede determinarse el punto en el que preferirán evitar una pena a cometer un delito.

Frente a la imposibilidad de conocer a priori las escalas de valores sobre las cuales los individuos basan sus decisiones, la Escuela Austríaca ha desarrollado el concepto de "preferencia demostrada”, según el cual “... la elección en sí revela, o demuestra, las preferencias del hombre; es decir, puede deducirse cuáles son sus preferencias a

22 Ibídem, p. 75. 
través de lo que ha elegido en la acción"23. Por ello, aun cuando puedan detectarse ciertas tendencias regulares en las conductas de los individuos que permitirían establecer un pronóstico respecto del modo en que reaccionarán frente a determinados estímulos, estos pronósticos siempre serán falibles y estarán sujetos a imprevistos cambios en las preferencias de las personas.

En nuestro caso de estudio, esto implicaría reconocer que, del hecho de que una persona se haya visto inhibida hoy de cometer un delito por la existencia de una amenaza cierta de recibir una pena, no puede lógicamente inferirse que esa misma amenaza lo disuada de realizar esa conducta mañana. Del mismo modo, del hecho de que determinada pena no disuada hoy a un individuo de lesionar a otro, o que la existencia de particulares condiciones socioeconómicas lo lleven a delinquir, no puede válidamente concluirse que bajo idénticas condiciones el mismo sujeto no actúe de otro modo en el futuro, simplemente porque su escala de valores se ha modificado. El análisis neoclásico, que solo ve "maximizadores amorales de utilidad", por el contrario, miraría con extrañeza al sujeto que ha decidido abandonar el camino del delito porque súbitamente tomó conciencia de sus peligros, tuvo una revelación mística, o por cualquier otra razón antojadiza que pudiera llevarlo a cambiar sus preferencias. Tal como lo sostiene Rothbard:

Todo lo que podemos decir es que una acción, en un momento determinado, revela parte de la escala de preferencias de un hombre en ese momento. No hay justificación alguna para suponer que permanece constante desde un momento determinado hasta otro ${ }^{24}$.

Además del rechazo a la idea de las preferencias estables, la teoría austríaca presenta un segundo obstáculo a la pretensión del análisis económico neoclásico de establecer correlaciones entre los niveles de penas esperadas por los posibles delincuentes y los índices de criminalidad: la idea de que no existen relaciones constantes entre magnitudes en la ciencia económica.

Esta cuestión se vincula en parte con la variabilidad de las preferencias de los individuos, y en parte con la imposibilidad de establecer una unidad de medida para cuantificar esas valoraciones.

En efecto, si no puede tenerse certeza respecto de las valoraciones futuras de los individuos, es imposible establecer una correlación precisa entre las fluctuaciones en determinadas variables y las acciones futuras de una persona o grupo de personas: del dato histórico que indica que el incremento en un año de la pena esperada

23 Murray Rothbard. "Hacia una reconstrucción de la utilidad y de la economía del bienestar", $L i$ bertas, n. ${ }^{\circ} 6$ (mayo 1987), Buenos Aires, ESEADE, 1987, p. 223.

24 Ibídem, p. 227. 
para el delito de robo se produjo una disminución del 10\% en ese tipo de crímenes, no puede inferirse que en un futuro, y en todos los casos, un incremento adicional de otro año en las penas esperadas produzca un efecto similar en el índice de robos.

Adicionalmente, cabe acotar que, dado que las escalas de valores en base a las cuales los individuos efectúan sus elecciones son magnitudes psicológicas, resulta imposible su medición y, por ende, establecer correlaciones entre distintas preferencias:

Las magnitudes psicológicas no pueden medirse ya que no existe ninguna unidad objetiva de medida, un requisito necesario para la medición. Además, la elección en sí evidentemente no puede demostrar ninguna forma de utilidad medible; sólo puede demostrar la preferencia por una alternativa en lugar de otra ${ }^{25}$.

Las acciones históricas, aun cuando revelan las escalas de valores de los individuos en determinado momento, tampoco permiten establecer el valor preciso otorgado a cada bien, ni el grado de preferencia otorgado a distintos bienes. Supongamos que una persona que venía llevando una vida honrada, decide cometer un robo tentada por un botín de U\$S 1.000.000. De dicha situación, lo único que podemos deducir es que esa persona, en ese momento, valoró más el millón de dólares que la posibilidad de perder temporalmente su libertad. Sin embargo, no podemos saber en qué punto exacto dejó de preferir la libertad al dinero, si ello aconteció en el dólar n..$^{\circ}$ 1.000.000, o si hubiera igualmente cometido el robo, por ejemplo, por U\$S 957.980, pero se hubiera abstenido por un centavo menos.

Como puede observarse, las escalas de valores no están conformadas de magnitudes continuas y perfectamente divisibles, dentro de las cuales pueda determinarse el punto exacto en que la preferencia por un bien dejará lugar a la preferencia por otro. Por ende, resulta inadecuado representar gráfica o matemáticamente las magnitudes psicológicas a los efectos de determinar sus interrelaciones, como lo pretende el AED penal neoclásico en su búsqueda de grados de disuasión perfectamente mensurables y penas socialmente eficientes.

En conclusión, aun cuando pueda existir cierta correlación entre la amenaza de pena y la disposición de los individuos a cometer delitos, y la utilización de fórmulas matemáticas tenga alguna utilidad para ilustrarla, lo que resulta científicamente incorrecto es pretender que tal correlación pueda ser precisada y utilizada para determinar los niveles de disuasión que supuestamente se corresponderían con cada nivel de pena esperada. 
Definitivamente no existe forma de establecer con precisión el modo en que reaccionarán los individuos frente a la amenaza de sufrir penas de distintas magnitudes, lo que socava uno de los pilares del AED penal neoclásico: si no tenemos modo de conocer cuántos policías, cuántos jueces, cuántos fiscales y qué penas necesitamos para alcanzar determinados índices delictivos, tampoco podremos establecer el costo de la disuasión del crimen.

Queda analizar, entonces, el otro presupuesto fundamental de la corriente tradicional del AED penal, que es la posibilidad de medir el costo social del delito, lo cual haremos seguidamente.

\section{III.C. La imposibilidad de medir el costo social del delito}

La gran aspiración del AED penal es maximizar el bienestar social, optimizando la cantidad de recursos destinados a la persecución y represión de conductas ilícitas, de modo tal que su costo se iguale con el costo social de los delitos disuadidos. La pregunta del millón es, entonces, cómo medir el costo social del delito, para lo cual, previamente, debemos aclarar a qué nos referimos cuando hablamos de costo del delito.

La idea de costo del delito admite tres acepciones: el costo individual, es decir el daño efectivamente padecido por la víctima; el costo de prevención, dentro del que deben computarse todos los recursos destinados a sostener el aparato judicial y policial en una determinada jurisdicción, y el costo social, noción esta última bastante difícil de caracterizar, en especial si la entendemos como algo más que la mera suma de los daños individuales padecidos por las víctimas.

En efecto, ¿de qué se trata este costo social que, según los teóricos del análisis económico, es preciso igualar con el costo de prevención para alcanzar un sistema penal eficiente? Para el enfoque que critico, se trata de un plus que el delito irroga a la sociedad al margen del daño concreto a la víctima, constituido básicamente por el miedo a padecer hechos similares. Al respecto, Cooter y Ulen señalan:

En el derecho penal, gran parte del daño es público. Consideremos que un homicidio amenaza a la paz y la seguridad de la sociedad en conjunto, de modo que hace temer por sus vidas a otros, además de la víctima ${ }^{26}$.

Robert Nozick, por su parte, explicita un poco más la idea de este modo:

Los daños públicos son aquellos a los que las personas les tienen miedo, aun cuando sepan que serán compensadas por completo si el daño ocurre. Aún bajo

26 Robert CoOter y Thomas Ulen. Ob. cit., p. 546. 
la más fuerte propuesta de compensación la cual indemnizará a la víctima por su miedo, algunas personas (las no víctimas) no serían compensadas por su miedo. Por tanto, hay un interés público y legítimo en eliminar estos actos de traspaso de límites, especialmente porque su comisión hace que todos tengan miedo de que les ocurra a ellos ${ }^{27}$.

En definitiva, el costo social del delito no es otra cosa que la suma de los daños efectivamente sufridos por las víctimas y el miedo que el crimen despierta en el resto de la sociedad.

Poner al miedo como fundamento del sistema penal abre una serie de interrogantes interesantes. El primero es si ese sentimiento tan difuso puede justificar moralmente la imposición de una sanción al delincuente, adicional a la obligación de resarcir el daño a la víctima. Pero aun dejando de lado esa cuestión, deberíamos preguntarnos: ¿Cómo puede medirse el miedo? ¿La imposición de castigos a los delincuentes puede reducir la sensación de temor de toda una sociedad? De ser ello así, ¿no podría alcanzarse idéntico resultado por otros medios?

En relación con el primero de estos interrogantes, es evidente que el miedo constituye una sensación tan subjetiva que ni siquiera tenemos una unidad de medida para cuantificarlo. No existe una metodología fiable para medir el miedo. El instrumento más utilizado hasta el momento, las encuestas, resulta deficiente en tanto no permite corroborar la veracidad de lo manifestado por los encuestados -que no siempre coincide con sus sensaciones reales-, ni caracterizar con precisión las respuestas obtenidas ${ }^{28}$. Ejemplo de esto último es que el miedo al delito percibido por los encuestados suele clasificarse en rangos tales como "alto", "medio" y "moderado", términos evidentemente imprecisos y que pueden interpretarse de modos muy diversos.

Por otro lado, la sensación de miedo al delito en ocasiones ni siquiera se corresponde con la posibilidad real de ser víctima de un delito. Es usual que las personas subestimen o sobreestimen la posibilidad de ser víctimas de un delito, ya sea por la influencia de los medios de comunicación, por el temor que les infunden ciertos cambios en los hábitos sociales, o por cualquier otra razón que puede o no tener asidero en hechos objetivos:

Tanto la percepción de inseguridad como el miedo al delito son percepciones y emociones subjetivas de los ciudadanos, y que no tienen por qué corres-

27 Robert Nozick. Anarquía, estado y utopía. Rolando Tamayo (trad.), México D.F., Fondo de Cultura Económica, 1988, p. 74.

28 Cfr. Laura Vozmediano, César San Juan y Ana Isabel Vergara. "Problemas de medición del miedo al delito. Algunas respuestas teóricas y técnicas", en Revista Electrónica de Ciencia Penal y Criminología, n. ${ }^{\circ}$ 10-07 (2008), Granada, Universidad de Granada, 2008, p. 5. Disponible en http:// criminet.ugr.es/recpc/10/recpc10-07.pdf (visitada el 24/3/2015). 
ponderse necesariamente con índices objetivos de seguridad y delito. Es más, frecuentemente se ha observado que la inseguridad ciudadana objetiva y la percibida son divergentes, y que en un contexto objetivo de delitos en decremento, crece, por distintas razones, la percepción de inseguridad ${ }^{29}$.

Esta última observación resulta interesante, dado que controvierte la premisa de que un grado mayor de disuasión reducirá significativamente el costo social del delito. Si el miedo de las personas es independiente de los índices delictivos reales, no puede establecerse entonces una correlación entre costos de disuasión y costos sociales del delito que permita determinar la cantidad óptima de recursos que deben destinarse al sistema penal. Podrían de hecho invertirse cuantiosos recursos en reducir los niveles de criminalidad (y lograrse tal objetivo con éxito) sin que el temor de las personas a ser víctimas de un delito disminuya necesariamente.

\section{III.D. ¿Quién define qué es delito?}

He venido hablando hasta aquí de "delitos" dando prácticamente por hecho que existen determinadas conductas que merecen una tipificación penal, sin detenerme a analizar los criterios que permiten distinguir aquellas acciones de otras que el sistema jurídico opta por dejar impunes. Traigo a colación el tema, puesto que una de las grandes falencias de la vertiente neoclásica del AED penal es, precisamente, la carencia de un criterio seleccionador de ese tipo.

En la práctica, el análisis económico tiende a dar por hecho que determinadas conductas están tipificadas como delitos y, partiendo de esa base, intenta concentrarse en la búsqueda del punto en que el costo social de tales actos se iguala al costo de su prevención.

El problema radica en que la tipificación penal no es un hecho "dado": ninguna acción humana es intrínsecamente un "delito". Muchas conductas pueden causar daños a otras personas, pero solo algunas de ellas tienen como consecuencia legal la aplicación de una pena en sentido estricto. Coincido al respecto en que:

Lo importante es que la criminalidad no es un fenómeno «natural», que no hay ninguna propiedad ontológica que haga de las acciones sociales de los individuos algo delictivo; ella resulta de un proceso político de criminalización, que depende de la tenencia del poder suficiente para aplicar las definiciones e instrumentos del control penal, neutralizando el conflicto y reprimiendo la divergencia seleccionada ${ }^{30}$.

29 Ibídem, p. 3.

30 Germán Silva García. "Una revisión del análisis económico del Derecho: una lectura crítica a propósito de la obra Crimen e Impunidad", Revista de Economía Institucional, n. $^{\circ} 2$, primer semestre 
En definitiva, la tipificación penal de una determinada conducta dependerá de una decisión política, que variará según las circunstancias, las valoraciones sociales o el antojo del legislador. El análisis económico carece de un criterio seleccionador propio que permita diferenciar las acciones lo suficientemente dañosas como para resultar merecedoras de pena de aquellas que no superan tal umbral.

En teoría, el legislador tendría que conocer el "costo social" de las distintas conductas potencialmente dañosas y el costo que implicaría disuadirlas con distintos grados de efectividad para así ajustar las variables hasta alcanzar el punto óptimo en que ambos costos se igualan. De este modo, quedarían exentas de tipificación aquellas acciones cuya disuasión, a cualquier nivel, resulta más onerosa que su permisión. Pero si, como ya vimos, las herramientas de la economía neoclásica resultan inidóneas para determinar el "costo social" de cualquier acción, entonces no queda otra opción que tomar los tipos penales ya establecidos por el legislador como punto de partida del análisis, independientemente del concreto daño provocado a las víctimas y a terceros.

Para ejemplificar la cuestión, pensemos en acciones usualmente consideradas de bagatela, tales como el hurto de un sándwich o un cordón de zapato: el costo de disuadirlas será en casi todos los casos superior al daño ocasionado a las víctimas, por lo que económicamente convendría su impunidad. Pero puede suceder que, en un caso concreto, esos bienes tengan un enorme valor para la víctima (vgr. el sándwich que estaba por almorzar quien padeció varios días de inanición), o que el legislador considere que la sociedad está particularmente sensibilizada por una ola delictiva, y por ello es preciso perseguir penalmente hasta la más mínima infracción. El AED neoclásico carece de instrumentos para establecer a priori las valoraciones en juego en esos casos, y por tanto no puede establecer por sí mismo qué conductas debería perseguir efectivamente el Derecho penal. La única forma de salir del atolladero es dar por supuesto que las conductas calificadas como delictivas por el legislador efectivamente deben ser reprimidas, sin saber a ciencia cierta en qué grado afectan a la sociedad, renunciando de ese modo a cualquier posibilidad de establecer niveles óptimos de disuasión que tiendan a la maximización del bienestar social.

Asumiendo, entonces, que la tipificación penal de una acción es producto de una política criminal y no de un razonamiento económico, podemos proseguir diciendo que dicha política puede adoptar básicamente dos orientaciones: la de proteger derechos individuales concretos, o la de tutelar un difuso interés social en la persecución del delito y la producción de seguridad.

En Occidente hemos optado en los últimos siglos por la segunda de tales posibilidades, "expropiando" lo que originalmente eran solo conflictos privados entre víc-

2000, Bogotá, Universidad Externado de Colombia, 2000, p. 180. 
timas y victimarios, para convertir ciertas acciones, arbitrariamente seleccionadas, en violaciones a un interés del Estado en mantener la paz social, concepto este último, además, cada vez más abstracto y desvinculado de la protección de derechos individuales concretos.

Esta concepción no solo no es cuestionada por el AED neoclásico, sino que es adoptada como propia. Sobre la cuestión, no es vano insistir en esta idea: desde que no existen las valoraciones sociales, sino que toda valoración es por definición individual, no hay modo de establecer en qué medida distintas conductas podrían dañar a la sociedad, y por lo tanto tampoco existe parámetro para decidir si resultaría socialmente más ventajoso dejarlas impunes o, por el contrario, intentar disuadirlas mediante el aparato represivo del Estado.

La consecuencia de aceptar que sea el Estado el que establezca qué acciones merecen ser objeto de persecución penal, tipificándolas con independencia del interés concreto de las víctimas, es un sistema en el cual toda pretensión de racionalidad resulta vana. Que no puede explicar racionalmente por qué se opta por reprimir ciertas conductas que no parecen afectar a nadie (los denominados "delitos sin víctima", como el consumo de drogas, la sodomía, etc.); que no posee parámetros para establecer la intensidad de la pena que merecen distintos tipos de delitos; que se propone "disuadir" sin saber a ciencia cierta qué es lo que merece ser disuadido o si las herramientas con las que dispone pueden alcanzar tal objetivo en alguna medida.

En conclusión, el AED penal, al menos en su versión neoclásica, carece de los instrumentos teóricos para determinar cuáles son las conductas que debe amenazar con pena el ordenamiento jurídico. Pero además, y lo que es peor, acepta sin justificación aparente el hecho de que sea el Estado el que "defina" los delitos, privando de tal posibilidad a quien, paradójicamente, tendría el interés más legítimo para adoptar tal decisión: la víctima. Comparto al respecto que

Considerar a la persecución de los criminales como un bien público, significa desconocer lisa y llanamente la posibilidad de que cada persona decida por sí misma, en primer lugar, si se considera víctima de un crimen o no; en segundo, si quiere o no perseguir al criminal, y por último, cuál será su reclamo concreto contra él. Esas decisiones íntimas y fundamentales son sustituidas por la imposición arbitraria y generalizada del gobierno a través de una ley ${ }^{31}$.

31 Ricardo Manuel Rojas. Las contradicciones del Derecho Penal, Buenos Aires, Ad-Hoc, 2000, p. 71 . 


\section{III.E. ¿Debería ser el Estado eficiente en la búsqueda de penas eficientes?}

Hemos abierto en el punto anterior un interrogante: ¿brinda el análisis AED neoclásico fundamentos sólidos para justificar la existencia de un poder punitivo estatal?

La respuesta afirmativa supone que el Derecho penal es un medio apto para prevenir el delito, y que un planificador estatal dotado de los instrumentos teóricos y técnicos adecuados resultaría idóneo para dosificar adecuadamente el poder represivo de modo tal de igualar su costo con las pérdidas ocasionadas a la sociedad por el accionar criminal. Aunque ya he planteado algunos cuestionamientos a tales presupuestos, vamos a insistir un poco sobre el punto, tratando de poner en evidencia que ni una ni otra afirmación es necesariamente cierta.

Ya vimos en el apartado III.A.2 que no existe evidencia empírica concluyente que permita establecer una correlación clara entre los niveles de pena esperada y los índices delictivos. De todas formas, aun cuando tal correlación pueda existir -aunque mucho más débil de lo que el AED neoclásico supone-, de la premisa según la cual el Estado puede hacer "algo" para combatir la criminalidad, no se sigue necesariamente que ese "algo" consista en crear más tipos penales, construir más cárceles y limitar las garantías procesales de los imputados. Insisto al respecto en que el delito es un fenómeno multicausal: las motivaciones que llevan a una persona a delinquir pueden ser muy variadas, y por ende no es lógico centrar todos los esfuerzos en atacar tan solo una de ellas. Otro tipo de medidas - que van desde mejorar el alumbrado público hasta incrementar las inversiones en centros deportivos- quizás sean tanto o más eficientes para reducir los índices delictivos, y sin embargo no despiertan tanta atención y entusiasmo como el Derecho penal.

Pero incluso suponiendo que una cantidad relevante de delitos puede ser efectivamente disuadida a través de la amenaza de la pena, ello no alcanza para justificar un orden jurídico en el cual la persecución penal es monopolizada por el aparato estatal, tal como acontece en buena parte de los sistemas penales modernos.

La consecuencia más evidente de esta monopolización estatal de la persecución penal es la de privar a la víctima de la posibilidad de decidir respecto del inicio de una acción judicial contra su victimario y, en todo caso, solicitar algún tipo de reparación material o moral que puede o no incluir el cumplimiento de una pena. Como enseña Bovino:

La principal consecuencia del principio de oficialidad es que el Estado conserva el monopolio persecutorio, monopolio que implica el poder de perseguir, el poder de juzgar o decidir sobre el derecho aplicable, y el poder de imponer y ejecutar la pena [...] El Estado no sólo detenta la pretensión penal, sino que 
tiene la facultad y la obligación de perseguir penalmente por sí mismo, sin consideración de la voluntad de las víctimas ${ }^{32}$.

Pero, ¿cuál es la razón económica que justifica la expropiación de la facultad de las víctimas de impulsar la persecución penal? ¿Cuál es el motivo que fundamenta la monopolización estatal del Derecho Penal?

\section{III.E.1. El Derecho penal como "bien público"}

El análisis económico neoclásico fundamenta la monopolización estatal del sistema penal en la teoría de los bienes públicos, según la cual, al ser la seguridad un servicio que beneficia a todos los miembros de la sociedad, sin posibilidad de que se excluya de sus efectos positivos a quienes no pagan por ella -es decir, el Derecho penal genera externalidades positivas, dicho en jerga económica-, y que debe ser brindado con idéntica calidad a todos sus usuarios, no existirían incentivos para que proveedores privados lo presten en cantidad y calidad suficientes ${ }^{33}$.

Para analizar si estos argumentos alcanzan para justificar la expropiación del conflicto penal hasta el punto en que, inclusive, es el propio Estado el que decide si impulsa o no los procesos con independencia del deseo de las propias víctimas -el denominado principio de oficialidad-, conviene detenernos a repasar un poco las nociones de bienes públicos y externalidades.

El concepto de bienes públicos comprende a aquellos bienes que reúnen dos notas características distintivas a las que ya nos hicimos referencia: la no exclusión y el consumo no competitivo. Tyler Cowen explica que

No exclusión significa que quienes no pagan no pueden ser excluidos de los beneficios del bien o servicio. Si un empresario prepara un espectáculo de fuegos artificiales, por ejemplo, la gente puede ver el espectáculo desde su ventana o desde su patio de atrás. Puesto que el empresario no puede cobrar una entrada por el espectáculo, puede que los fuegos artificiales no lleguen a celebrarse nunca, aunque la demanda del show sea grande.

El segundo aspecto de los bienes públicos es lo que los economistas llaman consumo no competitivo. Supongamos que el empresario consigue excluir a

32 Alberto Bovino. Principios políticos del procedimiento penal, Buenos Aires, Del Puerto, 2009, p. 6.

33 Cfr. Ricardo Manuel Rojas. Ob. cit., p. 59. 
los no contribuyentes de contemplar el espectáculo (quizás el espectáculo sólo pueda verse desde un campo privado). Se cobrará un precio por entrar en el campo, y la gente que no esté dispuesta a pagar este precio será excluida. Si el campo es lo suficientemente grande, sin embargo, la exclusión será ineficaz puesto que incluso aquellos que no paguen podrán contemplar el espectáculo sin incrementar el coste del mismo ni disminuir la diversión de los demás. Esto es el consumo no competitivo para ver el espectáculo ${ }^{34}$.

La idea de externalidad, por su parte, hace referencia a los efectos positivos o negativos que el accionar de una persona tiene sobre terceros y que no son debidamente compensados a través del sistema de precios, ya sea mediante el pago por el beneficio recibido o a través de la indemnización del perjuicio causado (ibídem).

Los conceptos de bien público y externalidad se encuentran, entonces, íntimamente vinculados: los bienes públicos producen, por definición, externalidades positivas que no pueden ser internalizadas, forzando a todos los beneficiarios a pagar por ellos y excluyendo de su goce a quienes no lo hacen.

La razón por la cual la teoría económica neoclásica propugna que los "bienes públicos" sean provistos por el Estado es que existen incentivos para que las personas intenten eludir su aporte para solventarlos, lo que conllevaría que sean producidos a niveles inferiores a los socialmente deseables. Como apunta Benegas Lynch:

En cualquier caso, en este contexto, se mantiene que los bienes públicos deben ser provistos por el gobierno, ya que de ese modo, se continúa diciendo, los beneficiarios de externalidades positivas financiarían el producto en cuestión vía los impuestos. Y, por tanto, no habría free-riders y, por ende, desaparecería esa «falla del mercado» (la producción de externalidades no internalizables). En este mismo hilo argumental se sostiene que si el gobierno no provee ese bien, el mercado no lo produciría o, si lo hiciera, sería a niveles sub-óptimos, puesto que los productores particulares tenderán a sacar partida de la externalidad especulando con la posibilidad de constituirse en un free-rider (es decir, a la espera de que otro sea quien lo produzca y, por tanto, cargue con los gastos correspondientes) $)^{35}$.

Hechas estas aclaraciones, precisemos ahora las razones por las cuales la seguridad ciudadana, supuestamente brindada por el Derecho penal, puede ser considerada un bien público.

34 Tyler Cowen. "Bienes públicos y externalidades”, en AA.vv., Enciclopedia Fortune de economía. DAVID HENDERSON (comp.), Barcelona, Folio, 1998, p. 20.

35 Alberto Benegas Lynch (H). "Bienes públicos, externalidades y los free-riders: el argumento reconsiderado", Libertas, n. 28 (mayo 1998), Buenos Aires, ESEADE, 1998, p. 201. 
Comúnmente se supone que, como es difícil excluir de los beneficios que la condena a un delincuente traería aparejados aun a quienes no han hecho nada para alcanzarla, nadie tendría suficiente interés en proveer un servicio privado de justicia penal. Los beneficios que la víctima obtendría de la persecución penal exitosa no serían, en la mayoría de los casos, suficientes para justificar el pago de un servicio privado que investigue el delito, colecte las pruebas, atrape al delincuente y lo someta a un tribunal. Pese a que todo ese proceso tendría como efecto un gran beneficio para el conjunto de la sociedad, muy pocas víctimas estarían, individualmente, interesadas en solventarlo: un sistema de justicia penal privado produciría sus servicios en niveles socialmente sub-óptimos.

En mi opinión, la idea de que los actores privados carecen de los incentivos necesarios para brindar servicios de persecución penal en cantidad acorde con las necesidades sociales solo puede ser cierta, sacando casos extremos como el de la represión del terrorismo internacional, partiendo de la base de que el Derecho penal debe ser tal y como lo es en la actualidad: un mecanismo pensado básicamente para cumplir la función de castigar conductas "desviadas", con independencia de los intereses de las víctimas, y sin brindar a estas ningún otro beneficio que no sea la satisfacción moral de haber contribuido a la consolidación de la justicia.

Ahora bien, una descripción respecto del "ser" no puede ser confundida con un juicio sobre el "deber ser". El hecho de que, dentro de un sistema penal que margina sistemáticamente a las víctimas, estas no tengan incentivos para solventar el aparato de persecución y represión criminal, no puede llevar a la conclusión de que ese es el mejor sistema de entre todas las alternativas posibles.

De hecho, es dable imaginar modelos alternativos de Derecho penal en los cuales las víctimas sí tendrían incentivos suficientes para solventar el funcionamiento del aparato coercitivo. Por ejemplo, si en lugar de únicamente castigar con una pena de prisión el delito de hurto, el Código Penal contemplara la posibilidad de extinguir la acción penal si el delincuente devuelve a la víctima los bienes sustraídos, le pide perdón, realiza trabajos en su favor durante un determinado lapso y asume el pago de las costas del proceso, podrían aparecer empresas privadas que brinden los medios necesarios para esclarecer ese tipo de hechos y llevar a sus autores ante los tribunales, así como numerosos "clientes" dispuestos a contratarlas.

El que podamos imaginar un sistema de persecución criminal en el cual las víctimas podrían obtener beneficios -el resarcimiento económico o moral-que no alcanzarían a quienes no pagan por el servicio, demuestra que el Derecho Penal no reúne necesariamente las características de un bien público, tal como lo postula el AED neoclásico.

La existencia de externalidades positivas tampoco parece un argumento muy consistente para sostener la monopolización estatal del sistema penal puesto que, del mismo modo en que nadie deja de usar perfume por el hecho de no obtener un pago 
por parte de todos quienes disfrutan el aroma, difícilmente alguien renunciaría a la posibilidad de obtener un resarcimiento por el crimen del que ha sido víctima por la circunstancia de que, al impulsar la persecución del delincuente, estaría gratuita e indirectamente contribuyendo a la seguridad del resto de la sociedad.

Lógicamente, podrían plantearse serias objeciones a la privatización completa del sistema de persecución penal. Existirían casos en los que, por ejemplo, los delincuentes carecerían de los recursos para reintegrar el pago de los gastos de investigación, persecución y juzgamiento. Ello podría derivar en situaciones injustas, como que las agencias privadas de investigación comenzaran a exigir a sus clientes el pago adelantado de honorarios, que las víctimas más pobres no estarían en condiciones de afrontar. Tales posibilidades darían, al menos en parte, la razón a quienes suponen que un sistema privado de persecución penal brindaría sus servicios en niveles sub-óptimos, o llevaría a la situación moralmente inaceptable de que el Derecho penal se convierta en un privilegio exclusivo para los sectores más pudientes de la sociedad.

Tales objeciones, aun siendo atendibles, no me alcanzan a convencer del carácter necesario del monopolio estatal de la persecución penal (podrían existir agencias privadas de persecución criminal trabajando en paralelo al sistema estatal, del mismo modo en que existen hospitales públicos funcionando a la par de innumerables clínicas privadas), ni tampoco de que deba vedarse a los particulares la disponibilidad de la acción penal. Aun cuando la existencia de un sistema público de justicia penal resulte necesaria, de ello no se deriva que tal aparato no pueda entrar en funcionamiento solo ante la solicitud de una parte interesada, del mismo modo en que lo hace la justicia civil.

\section{III.E.2. El problema de la planificación centralizada}

Suponer que el monopolio estatal de la persecución penal resulta un medio idóneo para la maximización del bienestar social, al permitir alcanzar un punto de equilibrio entre el daño causado por la actividad criminal y el costo de su prevención, implica también ignorar las razones por las cuales ningún órgano de planificación centralizada posee (ni puede poseer) las herramientas necesarias para asignar recursos eficientemente.

Vimos ya que nadie posee en realidad los instrumentos técnicos para determinar los distintos niveles de disuasión que se derivarían de cada nivel de inversión pública en el aparato de justicia penal, ni tampoco para establecer el costo social que generaría cada delito en particular. Ello no obedece, en rigor de verdad, a una limitación tecnológica que pueda llegar a ser superada, sino a la naturaleza subjetiva y cambiante de las valoraciones de delincuentes y víctimas. 
En este sentido, la razón por la cual un ente monopólico estatal no puede gestionar eficientemente un sistema penal no difiere en absoluto del motivo por el cual un planificador centralizado no puede producir eficientemente tomates, cortes de pelo, canciones bailables o cualquier otro bien: la imposibilidad de coordinar información dispersa y en constante cambio sin un sistema de "señales" adecuado.

Como lo señala Hayek, el problema que debe resolver la ciencia económica no es el de asignar recursos escasos de modo tal de satisfacer de la mejor forma posible unos fines determinados, sino el de coordinar información fragmentada y cambiante respecto del tipo de recursos con que se cuenta y los fines que se desea satisfacer:

El carácter peculiar del problema de un orden económico racional está determinado precisamente por el hecho de que el conocimiento de las circunstancias que debemos utilizar no se encuentra nunca concentrado ni integrado, sino que únicamente como elementos dispersos de conocimiento incompleto y frecuentemente contradictorio en poder de los diferentes individuos. De este modo, el problema económico de la sociedad no es simplemente un problema de asignación de recursos "dados" -si "dados" quiere decir dados a una sola mente que deliberadamente resuelve el problema planteado por estos "datos"-. Se trata más bien de un problema referente a cómo lograr el mejor uso de los recursos conocidos por los miembros de la sociedad, para fines cuya importancia relativa solo ellos conocen. $\mathrm{O}$, expresado brevemente, es un problema de la utilización del conocimiento que no es dado a nadie en su totalidad ${ }^{36}$.

Para Hayek, el modo más racional de resolver el problema de la mutabilidad y dispersión del conocimiento es la descentralización de la toma de decisiones, de modo de dejarla en manos de aquellas personas con mayor cercanía a la información relevante en cada caso:

Si estamos de acuerdo en que el problema económico de la sociedad se refiere principalmente a la pronta adaptación a los cambios según circunstancias particulares de tiempo y lugar, se podría inferir que las decisiones finales deben dejarse a quienes están familiarizados con estas circunstancias, a quienes conocen de primera mano los cambios pertinentes y los recursos disponibles de inmediato para satisfacerlos. No podemos esperar resolver este problema comunicando primero todo este conocimiento a una junta central, la que, después de integrarlo, dicta órdenes. Es preciso resolverlo por medio de alguna forma descentralizada ${ }^{37}$.

36 Friedrich VON HAYeK. "El uso del conocimiento en la sociedad", Estudios Públicos, n. ' 12, Santiago de Chile, Centro de Estudios Públicos,1983, p. 158.

37 Ibídem, p. 163. 
Cuando son posibles las transacciones voluntarias, el problema de la coordinación de múltiples decisiones individuales respecto del empleo de los recursos existentes se resuelve a través del mecanismo de mercado, o más específicamente gracias al sistema de precios. La teoría económica ha demostrado que las fluctuaciones en los precios relativos de los bienes permiten orientar los recursos hacia sus usos más eficientes de un modo mucho más rápido y eficaz que cualquier sistema de toma de decisiones centralizado. Así, por ejemplo, si súbitamente aumenta la valoración social de un bien (como podrían serlo los antibióticos ante una epidemia, o las bufandas frente a una ola de frío), su precio se incrementará correlativamente, incentivando a los empresarios a destinar más recursos a su producción, reduciendo paralelamente la producción de bienes menos valorados. Al respecto, podemos decir que

Para comprender la verdadera función del sistema de precios -función que, naturalmente, cumple en forma menos perfecta cuando los precios se vuelven más rígidos- debemos considerar dicho sistema como un mecanismo para comunicar información [...] El hecho más significativo acerca de este sistema es la economía de conocimientos con que opera, o lo poco que necesitan saber los participantes individuales para poder tomar la decisión correcta. En resumen, mediante una especie de símbolo, se comunica sólo la información más esencial y sólo a quienes les concierne ${ }^{38}$.

Si bien el Derecho penal no se ocupa de los resultados de transacciones libres y voluntarias sino que, por el contrario, un delito es por definición un acto que se realiza en contra de la voluntad de alguien ${ }^{39}$, el enfoque económico predominante trata a la pena esperada de modo análogo a un precio, a través del cual podría regularse la "oferta" de actos criminales. Desde esta óptica, resulta sorprendente que los teóricos del AED penal suelan inclinarse por proponer un sistema en el cual esos "precios" son fijados de modo monopólico y centralizado, en lugar de optar por un mecanismo que permita que sean los propios involucrados quienes determinen descentralizadamente las penas correspondientes a cada delito, reflejando de este modo tanto las valoraciones subjetivas de los bienes jurídicos tutelados por las normas penales, como sus variaciones a través del tiempo.

Un sistema centrado en el ejercicio privado de la acción penal, que además permitiese la aplicación de sanciones y compensaciones negociadas entre víctimas y victimarios, podría reflejar con mucha mayor fidelidad la verdadera importancia que dan los miembros de la sociedad a los distintos bienes jurídicos, teniendo además una

38 Ibídem, p. 165.

39 A excepción, claro está, de los denominados delitos sin víctima, que reprimen transacciones voluntarias, tales como el tráfico de drogas y que, en el enfoque que sostengo, deberían ser desterrados definitivamente del ámbito del Derecho penal. 
mayor flexibilidad ante los cambios valorativos en comparación a la que podría tener un sistema donde los "precios" sean fijados lenta y arbitrariamente por el legislador.

La creencia de que un órgano estatal centralizado puede ajustar las distintas variables de un sistema penal (tipo e intensidad de las sanciones, recursos humanos y tecnológicos destinados a la investigación y represión del delito, etc.) hasta alcanzar el punto de equilibrio entre sus costos y el costo social del delito, parte de cierta incomprensión respecto de la naturaleza del proceso de mercado. Según esta visión, el mercado sería un mecanismo para asignar todos los recursos existentes de modo eficiente, antes que un sistema para coordinar información dispersa y en constante cambio. Más aún, el AED neoclásico presupone que las preferencias individuales y ciertas variables exógenas -que pueden ir desde el clima a la tasa de desempleo- permanecen estables a lo largo del tiempo, o al menos varían con la suficiente lentitud como para permitir a un órgano centralizado captar y procesar sus cambios.

Sin embargo, tal como lo explica Israel Kirzner, si bien el sistema de precios permite la coordinación de acciones individuales en un proceso equilibrante, eso no significa que tal equilibrio se alcance alguna vez, puesto que las prefererencias, dotación de recursos y posibilidades tecnológicas cambian con frecuencia, interrumpiendo esos procesos equilibrantes e induciendo otros nuevos ${ }^{40}$. Estos cambios y fluctuaciones son la razón misma para que exista tal cosa como un proceso de mercado, y son el motivo por el cual es mejor dejar que los individuos tomen libremente sus decisiones con base en sus conocimientos y preferencias particulares, antes que confiarlas en un planificador centralizado.

Entonces, si se asimila la expectativa de pena a un "precio", lo más lógico es fijarla a través de un mecanismo que se asemeje en la mayor medida posible a un mercado competitivo. Y ello no por un prejuicio ideológico a favor de la economía de mercado, sino porque el concepto de precio solo tiene sentido cuando es el producto de un proceso de intercambio libre que refleja las fluctuaciones en las preferencias individuales.

En este orden de ideas, no podemos esperar que un sistema de penas fijadas por el legislador prescindiendo de la voluntad de víctimas y acusados opere como incentivo para conducir los índices delictivos hacia niveles socialmente eficientes, puesto que así como los precios establecidos arbitrariamente conducen a la sobreoferta o escasez artificial de bienes, según estén por encima o por debajo del precio real de mercado, una pena esperada impuesta en abstracto por un monopolio estatal traerá como consecuencia una mala asignación de los recursos destinados a la prevención

40 Cfr. IsRaEl KIRZNER. "El significado del proceso de mercado”, Libertas, n. o 27 (octubre 1997), Buenos Aires, ESEADE, 1997, p. 129. 
del crimen, la cual estará por encima o por debajo de las efectivas necesidades de la sociedad.

Ningún órgano centralizado -privado o estatal-, por más complejas y sofisticadas investigaciones psicológicas, sociológicas, históricas o económicas que realice, puede llegar a determinar las reales preferencias de los individuos como para establecer un régimen de sanciones eficientes. Es imposible tanto conocer a priori cuál será la pena que efectivamente disuadiría a un individuo específico de delinquir, como establecer cuál es el valor subjetivo que la víctima de un ilícito adjudica al daño que sufrió, máxime si no permitimos que se haga explícita tal valoración mediante la formulación de un pedido concreto de reparación dirigido al imputado.

\section{UNA CRÍTICA AXIOLÓGICA}

Aun cuando el eje de este trabajo consista en el análisis crítico de los presupuestos teóricos del AED penal neoclásico, no quisiera dejar de dedicar algunos párrafos a plantear algunas objeciones -llamémoslas morales-a las propuestas normativas de este enfoque.

Antes de avanzar, y como en materia de ideas morales no existen parámetros objetivos ni verdades reveladas, aclaro una vez más que mis objeciones parten de una cosmovisión liberal, en la cual la autonomía individual es el valor supremo de toda ponderación. La idea fundamental del sistema de valores liberal es que cada individuo es un fin en sí mismo y no un medio para alcanzar fines ajenos. La única razón válida para limitar la libertad de un individuo de perseguir su propio plan de vida, es la de asegurar idéntica libertad a sus semejantes. Como sostiene Nozick, para el liberalismo "... los individuos son fines, no simplemente medios; no pueden ser sacrificados o usados, sin su consentimiento, para alcanzar otros fines. Los individuos son inviolables" 41 .

Desde este punto de vista, resultan casi obvias las objeciones que merece la idea de que el sufrimiento de un individuo -materializado a través de la pena- pueda ser utilizado deliberadamente como medio para la prevención del delito. De ahí que, por lo general, los autores liberales rechacen la prevención general como principio legitimante del Derecho penal y prefieran recurrir, como principios validantes, a las ideas de retribución o prevención especial.

Desde luego que el liberalismo que defiendo no desconoce que las sanciones penales - en abstracto- tienen la función de reforzar las prohibiciones contenidas por el ordenamiento jurídico general y, por ende, un efecto al menos simbólico tendiente a

41 Robert Nozick. Ob. cit., p. 43. 
la prevención general de las conductas jurídicamente disvaliosas. Ello es, diría, casi una imposición de la lógica jurídica que ningún enfoque puede soslayar. Tal como lo sostuviera uno de los grandes juristas del siglo $\mathrm{xx}$ :

Considerado en cuanto a su fin, el derecho aparece como un método específico que permite inducir a los hombres a conducirse de una manera determinada. El aspecto característico de este método consiste en sancionar con un acto coactivo la conducta contraria a la deseada. El autor de una norma jurídica supone evidentemente que los hombres cuya conducta es así regulada considerarán tales actos de coacción como un mal y se esforzarán por evitarlos. Su meta es, pues, encauzarlos hacia una conducta determinada, amenazándolos con un mal en caso de una conducta contraria, y es por la presión que así ejerce sobre ellos como obtiene lo que desea ${ }^{42}$.

Ahora bien, una cosa es admitir que toda sanción jurídica, mientras se mantiene como mera expectativa, busca de algún modo disuadir determinadas conductas, puesto que ello es lo que distingue las normas jurídicas de otros tipos de normas (como las morales o éticas), y muy otra es condicionar las formas de aplicación concreta de esa sanción a un individuo a consideraciones referentes al potencial efecto disuasivo que tendría sobre el resto de la comunidad. Existe una diferencia fundamental entre imponer a una persona el acatamiento de reglas que tienden a posibilitar la convivencia social, acompañándolas de sanciones destinadas a inducir su cumplimiento, y convertir a ese mismo individuo, una vez que ha violado la norma que le ha sido impuesta, en un medio para intimidar a terceros.

Para el liberalismo la pena es un mal tolerable en tanto respete la autonomía individual, en el sentido de no intentar transformar a la persona en un medio para la persecución de fines que le son ajenos. Es decir, en tanto meramente acote las vías que el individuo tiene a su disposición para alcanzar sus propios fines-cualesquiera que estos sean-, en la medida estrictamente necesaria para asegurar idéntica posibilidad a sus semejantes. En este sentido podemos interpretar la opinión de Hayek, cuando dice:

Por lo menos en todos los casos en que la coacción con que amenaza es evitable, el único efecto de la ley consiste en alterar meramente los medios a mi disposición, pero nunca en determinar los fines que he de perseguir. Sería ridículo decir que al firmar un contrato obedezco la voluntad de otro, cuando no podría haberlo concluido si no existiera una regla reconocida que me promete que se mantendrá lo pactado; o bien que existe subordinación a la

42 Hans Kelsen. Teoría pura del Derecho, segunda edición. Moisés Nilve (trad.), Buenos Aires, Eudeba, 1960 , pp. 72 y 73 . 
voluntad de otro al aceptar las consecuencias legales de cualquier acción que yo realice con pleno conocimiento de la ley ${ }^{43}$.

Por el contrario, la pena deviene inmoral cuando se transforma en un mecanismo a través del cual unas personas son utilizadas como ejemplo del mal que sufrirán otras en caso de violar los mandatos establecidos por el legislador. En este caso se viola la dignidad del ser humano al transformarlo en un simple medio a través del cual quienes legislan intentan imponer sus propios fines a otros individuos.

A continuación intentaré desarrollar mejor estas ideas.

\section{IV.A. El ser humano como fin y no como medio}

Desde este punto de vista, resultan casi obvias las objeciones que merece la idea de que el sufrimiento de un individuo -materializado a través de la pena- pueda ser utilizado deliberadamente como medio para la prevención del delito. De ahí que, por lo general, los autores liberales rechacen la prevención general como principio legitimante del Derecho penal y prefieran recurrir, como principios validantes, a las ideas de retribución o prevención especial.

Desde luego que el liberalismo que defiendo no desconoce que las sanciones penales -en abstracto- tienen la función de reforzar las prohibiciones contenidas por el ordenamiento jurídico general y, por ende, un efecto al menos simbólico tendiente a la prevención general de las conductas jurídicamente disvaliosas. Ello es, diría, casi una imposición de la lógica jurídica que ningún enfoque puede soslayar. Tal como lo sostuviera uno de los grandes juristas del siglo XX.

Si el AED neoclásico se limitara a resolver los casos de Derecho penal del mismo modo en que resuelve la mayoría de los problemas de transacciones no voluntarias (vgr. responsabilidad civil extracontractual), el problema de instrumentalización de los condenados en buena parte no se presentaría. En ese supuesto, la pena óptima se establecería de modo tal que resulte una compensación adecuada por los daños causados a la víctima (económicos, psicológicos, morales, etc.), más los gastos incurridos en el transcurso de la investigación criminal y el proceso judicial, por lo que se tendería a alcanzar una asignación de recursos que maximice el bienestar de la sociedad, lo más próxima posible a aquella que resultaría de transacciones voluntarias. Como ya mencioné, en esta hipótesis la pena no sería para el delincuente otra cosa que el costo esperable del curso de acción elegido para satisfacer sus propios fines.

43 Friedrich VON HAYEK. Los fundamentos de la libertad, tercera edición. José Vicente Torrente (trad.), Madrid, Unión Editorial, 1975, p. 203. 
La objeción moral en contra de la instrumentalización del reo surge cuando en la determinación de las penas “óptimas" entra a terciar, además del daño a la víctima y los costos procesales, el llamado daño social. Cuando una parte significativa de la pena se transforma en un medio para disuadir a terceros de que cometan actos a los que cierto número de miembros de la sociedad teme, el delincuente se transforma en una mera herramienta empleada para apaciguar ese temor. La persona condenada deja de ser un individuo libre que está "pagando" por el daño causado a un semejante, para obrar como una suerte de cartel de advertencia destinado a atemorizar a otros individuos. Su dignidad se ve menoscabada al ser tratada como cualquier otro instrumento que pudiera haber sido utilizado con el mismo fin (una cerca electrificada, un perro guardián o un patrullero estacionado en una esquina).

¿Por qué motivo debemos considerar moralmente aceptable esta cosificación de un individuo en aras del interés ajeno? ¿Cuál es el procedimiento lógico que permite establecer que el interés de algunos miembros de la sociedad en desalentar ciertas conductas debe prevalecer sobre los fines perseguidos por la persona a la que se condena? ¿Por qué la libertad del ladrón es menos valiosa que el temor -quizá infundado- de aquellos a quienes no ha robado? Como lo sostiene Nozick, apelar a una esquiva noción de bien común en estos casos es recurrir a un argumento falaz, puesto que "... no hay nada que moralmente prepondere sobre una de nuestras vidas en forma que conduzca a un bien social general superior. No hay ningún sacrificio justificado de alguno de nosotros por los demás" 44 .

En la concepción que critico, el carácter instrumental de los condenados llega a tal punto que su sufrimiento podría justificarse aun cuando sus actos no sean considerados dañosos por la propia víctima. Un buen ejemplo es la persecución penal del tráfico de drogas, que lleva al encarcelamiento de miles de personas que se limitan a realizar transacciones voluntarias ( el consumidor de drogas no considera al traficante como un victimario, sino simplemente como el proveedor de un producto que desea!), por el mero hecho de que un sector de la sociedad rechaza o teme el consumo de estupefacientes. El traficante encarcelado no purga una condena por haber dañado los derechos de alguien, sino porque la sociedad precisa de su sufrimiento para llevar adelante su cruzada contra las drogas: es utilizado como medio para alcanzar fines ajenos a la supuesta víctima y a él mismo.

Para colmo, dado que el temor frente a distintos hechos se exacerba crecientemente en las sociedades modernas - generando una mayor "demanda" de penas- la lógica de la eficiencia económica justificaría la imposición de padecimientos cada vez mayores a los delincuentes. En la medida en que crece el temor, crece el "costo social", y con ello deviene eficiente destinar cada vez más recursos a la persecución del delito. Como apunta Christie:

44 Robert Nozick. Ob. cit., p. 45. 
Vivimos la situación concreta del delito como fenómeno masivo. La furia y la ansiedad originadas por los actos que en las sociedades modernas también se podrían considerar como delitos naturales se convierte en la fuerza motora de la lucha contra todo tipo de delitos. Esta nueva situación, con una reserva ilimitada de actos que pueden definirse como delitos, también crea ilimitadas posibilidades de lucha contra todo tipo de actos no deseados ${ }^{45}$.

Vemos pues que la concepción neoclásica del AED penal no solo permite la utilización de algunos individuos como medios para alcanzar los fines de la sociedad-lo cual se contrapone al principio moral liberal según el cual la función del Estado es tutelar la autonomía individual-, sino que además permite la tipificación de delitos sin víctimas y el aumento persistente de las penas. Además, como veremos, es escaso el interés de esta corriente en la preservación de derechos individuales elementales en materia penal, que más bien tiende a dejar de lado en aras de un supuesto bienestar social.

\section{IV.B. Neoutilitarismo y derechos individuales}

Las dificultades que enfrenta el enfoque neoclásico para justificar coherentemente el respeto por las más elementales garantías del Derecho penal liberal no ha sido tampoco una preocupación ajena a algunos de los propios teóricos de la corriente. Así, se ha observado que

Tanto los modelos económicos como los retributivos tienen dificultades para racionalizar algunas políticas adoptadas o al menos reconocidas por la mayoría de los sistemas penales modernos: las prescripciones económicas parecen inconsistentes con las restricciones constitucionales respecto de los castigos crueles e inusuales... ${ }^{46}$.

Pareciera ser que la eficiencia económica, tal como la entienden los teóricos neoclásicos, exigiría dejar de lado algunos principios que hacen al respeto de derechos humanos fundamentales, tales como la presunción de inocencia, la proporcionalidad de la pena, la ultraactividad de la ley más benigna, etc. Y aun cuando ocasionalmente se han elaborado justificaciones económicas para sostener tales principios, por lo general se trata de argumentos ad hoc, destinados a hacer más digerible el AED a sus detractores. El neoutilitarismo implícito en las soluciones del análisis económico

45 Nils Christie. La industria del control del delito. Sara Costa (trad.), Buenos Aires, Del Puerto, 1993, p. 31

46 Kenneth Avio. "The economics of prisons", en Aa.vv., Encyclopedia of Law and Economics. Volume V. The Economics of Crime and Litigation. BoudewiJn BoucKAERT, GerRit De GeEst (eds.), Cheltenham, Edward Elgar, 2000, p. 395. 
neoclásico no pareciera ser, en rigor, demasiado congruente con las restricciones al poder punitivo propias del Derecho penal liberal.

Esta tensión entre las prescripciones del análisis económico y los principios elementales del Derecho penal se hace evidente en materia de proporcionalidad de las penas. Allí donde tradicionalmente se ha entendido que la justicia exige cierta proporción entre el castigo y el daño causado por el delito, la introducción del "daño social” en la ponderación introduce un factor de desequilibrio que justificaría el agravamiento de las penas más allá de lo históricamente considerado razonable. En tiempos de exacerbada paranoia frente al delito, la desmesurada sensación de pánico provocada por conductas en sí mismas poco significativas pareciera justificar una cada vez mayor ampliación del poder punitivo.

Supongamos que una ola de violentos robo de automóviles desatara una ola de pánico colectivo frente a este tipo de delitos. En ese caso, el costo social del robo de automotores se incrementaría exponencialmente, por lo que el nivel de pena esperada para ese tipo de hechos podría ser considerado socialmente ineficiente, en tanto permitiría la impunidad de una cantidad de robos cuyo costo de disuasión sería menor a la ganancia social" que podría obtenerse aumentando las penas o incrementando la cantidad de policías, cárceles, jueces, etc. Dado que, para alcanzar idénticos niveles de sanción esperada, es más barato aumentar la intensidad de las penas que incrementar la probabilidad de detección de los delitos, seguramente se optaría por un endurecimiento de las escalas penales. ¿Qué impediría en este caso imponer la prisión perpetua por robo de automóviles, o asignarle a ese delito una pena similar al homicidio (máxime si suponemos que, en las particulares circunstancias del caso, las personas suponen más probable y, por ende, temen con más intensidad, el ser robadas violentamente que asesinadas)?

La respuesta que el análisis económico neoclásico da para justificar la existencia de sanciones de diferente intensidad para cada tipo de delitos, es que si todos ellos tuvieran la misma pena, al delincuente le resultaría más conveniente cometer los crímenes más graves. Cooter y Ulen lo explican con este ejemplo:

... supongamos que la cadena perpetua es el castigo máximo de que dispone una sociedad, y que la ley prescribe la cadena perpetua para el abuso de confianza. Supongamos ahora que un policía corre tras un abusador que tiene una pistola. Si el policía aprehende al abusador, éste será encarcelado de por vida como lo requiere la severa ley. Por lo tanto, el abusador podría tratar también de disparar contra el policía. Si el abusador logra matar al policía, escapará. Si falla, no habrá ningún castigo adicional porque el castigo para el abuso de confianza es ya el máximo. En este ejemplo, los castigos severos para delitos menos graves minan la disuasión de delitos más graves ${ }^{47}$.

47 Robert Cooter y Thomas Ulen. Ob. cit., pp. 566 y 567. 
Ahora bien, esta explicación lo único que señala es que debe existir una diferenciación entre la pena aplicable a distintos hechos, y que los delitos más graves deben ser sancionados con penas más intensas. Sin embargo, este principio no exige ningún tipo de proporción no ya entre los distintos tipos de delitos, sino entre el daño causado por cada uno de ellos y la pena que le resulta aplicable. En tanto se guarde la proporción entre los distintos tipos de delitos, nada impide que el robo se sancione con prisión perpetua, en la medida que el homicidio se castigue con pena de muerte.

No debe extrañarnos, entonces, que la irrupción de los argumentos economicistas haya sido contemporánea a un proceso de incremento generalizado de las penas y la población carcelaria en la mayor parte del mundo occidental, al cual muchos, con razón, han calificado de inflación penal. Como ejemplo de tal situación, podemos mencionar que mientras los niveles de encarcelamiento en los EEUU en la primera mitad de la década de 1990 (los cuales casi cuadruplicaban la media europea $)^{48}$ eran considerados eficientes para varios economistas ${ }^{49}$, para un conocido teórico abolicionista implicaban niveles de encarcelamiento "enormes" y "sorprendentes", que abrían perspectivas "aterradoras" 50 .

Ciertamente, el principio de proporcionalidad no es el único amenazado por el mal uso de la economía aplicada al análisis del Derecho penal. Lo mismo ocurre con otros principios fundamentales del liberalismo penal, como por el ejemplo el de culpabilidad.

Como es sabido, el principio de culpabilidad implica que una persona solo puede ser penada en la medida en que haya realizado una acción previamente descripta en un tipo penal, y que además esa acción pueda serle atribuida subjetivamente, por haber actuado voluntariamente con conocimiento de la violación al mandato jurídico y teniendo la posibilidad de obrar adecuándose a él. Su importancia radica en que excluye la posibilidad de que sean penados quienes no han intervenido en el hecho tipificado por la norma penal, no han comprendido la criminalidad del acto o bien no han tenido la posibilidad de obrar de modo acorde al mandato jurídico. Tal como lo afirma Ferrajoli:

... los [...] sistemas que incluyen la garantía de la responsabilidad "personal", "subjetiva" o "culpable", se distinguen de todos los demás porque vetan la responsabilidad impersonal, objetiva o no culpable, configurando las hipó-

48 Cfr. Nils Christie. Ob. cit., pp. 22 y 37, quien menciona que el índice de encarcelamiento en los EE.UU. en 1990 era de 504 presos por cada 100.000 habitantes, mientras que para el mismo año el índice en Gran Bretaña era de 90, en Alemania de 88, en España de 86, en Francia de 82 y en Noruega de 56.

Cfr. Kenneth Avio. Ob. cit., p. 421.

50 Cfr. Nils Christie. Ob. cit., p. 89. 
tesis de falta de alguno de los tres elementos de la culpabilidad como otras tantas "causas subjetivas de exclusión del delito". Precisamente, el delito y la consiguiente responsabilidad quedan en ellos excluidos: a) por las causas de exclusión de la personalidad o de la suidad de la acción, como ocurre en los hechos ajenos o en el caso fortuito; b) por las causas de exclusión de la imputabilidad del autor, como la enfermedad mental o la minoría de edad; c) por las causas de exclusión de la culpabilidad en sentido estricto, como la inconsciencia involuntaria, la fuerza mayor, el constreñimiento físico o los distintos tipos de error ${ }^{51}$.

Desde una perspectiva liberal, está claro que bajo ningún punto de vista resulta aceptable penar a una persona inocente o que, en el caso concreto, fue incapaz, por una razón ajena a su voluntad, de motivarse en la norma. Desde la óptica del análisis económico neoclásico no resulta tan claro que, en algunos casos, aplicar una pena en tales condiciones no pueda contribuir a maximizar la riqueza social.

Imaginemos un crimen de gran repercusión social, como podría ser un atentado con explosivos que mata a varias personas. Iniciada la investigación, la policía descubre que el autor obró bajo los efectos de un poderoso alucinógeno ingerido accidentalmente con la comida. O ni siquiera eso: pensemos que la policía no encuentra al autor del hecho, pero sí a un sospechoso que reúne todas las condiciones para convertirlo en un "culpable" creíble. Moralmente, resultaría inaceptable tanto penar a una persona que no ha podido dirigir sus actos como a un inocente. Pero, quizás, si fuera necesario frenar una ola de pánico colectivo, o se tuviera la certeza que la aplicación de una sanción "ejemplificadora" podría evitar otros atentados terroristas, penar a un chivo expiatorio podría redundar en un incremento de la riqueza social y ser considerado económicamente eficiente.

Podría objetarse que penar a quien no ha tenido capacidad de comprender la criminalidad de sus actos no tendría efectos disuasivos considerables, puesto que claramente no serviría para disuadir a otras personas en situación de error o inimputabilidad y, por lo tanto, una condena en tales condiciones, además de una injusticia, implicaría un vano despilfarro de recursos.

¿Pero qué pasaría si condenar a un inimputable sirviera, no ya para disuadir a otros inimputables, sino a quienes se encuentran en pleno uso de sus facultades? En este sentido, cabe observar que, en la medida en que la incapacidad del acusado para obrar culpablemente no se haga pública, el efecto disuasivo de la condena respecto de terceros sería idéntico al de cualquier otro caso.

51 Luigi Ferrajoli. Derecho y razón, $9^{a}$ ed. Perfecto Andrés Ibañez, Alfonso Ruíz Miguel, Juan Carlos Bayón Mohino, Juan Terradillos Basoco, Rocío Cantarero Bandrés (trads.), Madrid, Trotta, 2009, pp. 490 y 491. 
Una segunda objeción que podría plantearse a la aplicación de penas prescindiendo de la evaluación de la culpabilidad del acusado sería la que Nozick formulaba a la posibilidad de reprimir todo tipo de actos dañosos, aun aquellos accidentales o inintencionales:

Penalizar todos los traspasos no consentidos, incluyendo los accidentales y los realizados sin intención, incorporaría una gran cantidad de riesgo e inseguridad en la vida de las personas. No obstante sus mejores intenciones, las personas no podrían estar seguras de no terminar siendo castigadas por sucesos accidentales ${ }^{52}$.

Es cierto que un sistema penal que permitiese condenar a inocentes o incapaces generaría, por sí mismo, la clase de temor en la población que supuestamente el aparato represivo del Estado está destinado a desterrar. En un orden jurídico en el que se permitiera indiscriminadamente sancionar a los individuos con prescindencia de su culpabilidad, al temor social frente al delito habría que sumarle el temor a ser injustamente condenado. Además, el efecto disuasivo de la pena se diluiría, puesto que siendo igualmente probable ser condenado tanto si se comete un delito como si no se lo hace, cualquier maximizador racional, en ausencia de restricciones morales, optaría por emprender el camino del crimen. Un sistema de tal naturaleza multiplicaría el costo social en lugar de minimizarlo.

Sin embargo, se me ocurre que, si se acotase la posibilidad de ser condenado injustamente y se dosificara adecuadamente la utilización de chivos expiatorios, un economista lo suficientemente creativo podría encontrar una fórmula matemática que maximizara, en teoría, la riqueza social. Por ejemplo, podría limitarse la posibilidad de aplicar penas prescindiendo del principio de culpabilidad solo a los miembros de determinados sectores sociales, y establecerse un cupo máximo de penas injustas. Imaginemos que solo se condena injustamente a las personas más pobres y que tal posibilidad se limita a un 5\% de los casos. El costo de imponer penas injustas se minimizaría, puesto que las personas a las que se aplicarían serían aquellas cuyo costo de oportunidad por ser encarceladas es más bajo (dado que es el grupo con menor capacidad para obtener ingresos estando en libertad). El costo producido por el temor a ser penado arbitrariamente también se reduciría, porque tal posibilidad estaría limitada a un pequeño número de casos, lo que también acotaría la merma en el efecto disuasivo de la pena. Haciendo los cálculos adecuados, este sistema podría ser útil, quizás, para minimizar el costo social del delito frente a crímenes particularmente sensibles a la opinión pública, y difíciles de resolver.

Claro está, el sistema que imaginamos sería moralmente repugnante, injusto y discriminatorio, pues contribuiría a empeorar las condiciones de vida de los sectores

52 ROBERT NozIcK. Ob. cit., p. 78. 
más pobres de la sociedad y resultaría contrario a las nociones más elementales de respeto a la dignidad humana. Pero, con todo, quizá podría ser calificado como económicamente eficiente, y de allí que sirva para ilustrar la clase de resultados axiológicamente inaceptables a los que podría llevar la aplicación de las herramientas del análisis económico neoclásico al Derecho penal: dentro de la perspectiva economicista que critico, el principio de culpabilidad sobrevive simplemente porque aún nadie ha encontrado las ecuaciones adecuadas para abolirlo.

Aún podríamos recurrir a otros ejemplos que ilustrarían la conflictiva relación entre las exigencias de una moral liberal y las prescripciones normativas del AED penal neoclásico. ¿Por qué deberíamos respetar el principio de ultraactividad de la ley penal más benigna? ¿Acaso la eficiencia no reclama que se imponga la pena más adecuada a la demanda actual de disuasión, aun cuando el acusado haya actuado bajo el imperio de una ley que imponía una sanción más leve? ¿Por qué, amparándonos en la presunción constitucional de inocencia, deberíamos permitir que personas acusadas de delitos graves esperen el dictado de su sentencia en libertad? ¿No resultaría más adecuado, para disminuir el temor del resto de la sociedad, mantener a esos acusados detenidos hasta que se lleve a cabo el juicio $\mathrm{y}$, si son hallados inocentes, indemnizarlos por el tiempo que han padecido privados de su libertad?

En definitiva, el análisis económico neoclásico no solo justifica la adopción de soluciones moralmente inaceptables en materia de Derecho penal, sino que en algunos casos implica un grave retroceso en la implementación de principios que han significado verdaderas conquistas históricas de la libertad individual frente a la arbitrariedad y la tiranía de los gobernantes. Existen ciertos principios que son esenciales al respeto por la dignidad humana y no deben ser negociados. Una teoría que vea con buenos ojos la aplicación de penas desmesuradas, o que permite el encarcelamiento de inocentes, no puede ser considerada, desde un punto de vista moral, como una buena teoría.

Ahora bien, que la aplicación de los conceptos de la economía neoclásica nos lleve a soluciones moralmente inaceptables, no significa que cualquier utilización de la economía al análisis del Derecho penal deba llevarnos a idénticos resultados. Creo que, si dejamos de lado la búsqueda de ilusorios puntos de equilibrio que maximizan la riqueza social, abandonamos la utilización de difusos agregados, y entendemos que la única transacción eficiente es aquella voluntariamente aceptada por las partes involucradas, tal vez podamos pensar un sistema penal que responda a las exigencias de la racionalidad económica y, al mismo tiempo, sea respetuoso de los derechos y libertades individuales. A explorar tal posibilidad dedicaré las próximas páginas.

\section{UNA PROPUESTA}

Hasta aquí he analizado algunos argumentos en contra de la versión usualmente aceptada del análisis económico de las instituciones del Derecho penal, identifica- 
da con lo que podemos denominar economía neoclásica. Desde luego no pretendo haber agotado el universo de aspectos potencialmente cuestionables de ese enfoque, ni tampoco ignorar que los cuestionamientos que he formulado pueden ser a su vez cuestionables e incluso refutados con buenos argumentos.

En mi modesta opinión, la economía neoclásica no aporta al Derecho penal más que un conjunto de preguntas interesantes, algunas respuestas innovadoras y otras decididamente peligrosas. De ningún modo resulta un enfoque lo suficientemente completo y coherente como para reemplazar el edificio conceptual que los penalistas han venido elaborando en los últimos tres siglos sin prestar explícita atención a las enseñanzas de la economía. Quizá uno de sus aspectos más cuestionables resida en la impotencia para brindar soluciones justas a casos concretos. Al trabajar con agregados, el AED parece haber renunciado a la posibilidad de dar respuestas satisfactorias a víctimas individuales o penas adecuadas a cada delincuente particular: privilegia el interés estadístico a las necesidades de los seres humanos de carne y hueso.

Sin embargo, creo que es posible reconciliar a la ciencia económica con una concepción liberal de la justicia y los derechos individuales. Un primer paso sería abandonar la difusa idea del interés público como elemento rector del Derecho penal. En consonancia con las más recientes corrientes penales - no necesariamente vinculadas a la economía-, creo que es preciso "reprivatizar" el conflicto penal, devolviéndole a víctima y victimario el lugar protagónico del proceso. En este sentido, resulta también preciso abandonar la concepción de la pena como instrumento de prevención o disuasión del delito, para devolverle el carácter de medio de reparación o compensación que supo tener alguna vez.

El eje de la propuesta normativa que desarrollaré a continuación pasa por devolverle al Derecho penal la condición de ultima ratio del ordenamiento jurídico propia de la tradición liberal, transformándolo más en un capítulo particular y complementario del Derecho de daños, que en un sistema normativo autónomo con objetivos propios y emancipados del propósito de resolver conflictos entre individuos concretos. Como lo sostiene Rojas:

... si la función del gobierno es proteger derechos individuales de personas concretas en los casos en los que éstas decidan demandar su protección, no se justifica la existencia de un procedimiento civil y otro criminal, el primero con el objeto de que la víctima obtenga una reparación patrimonial por el daño sufrido, y el segundo para imponer algún otro tipo de castigo al criminal, en nombre de la "sociedad" o el "Estado" 53 . 
No temo equivocarme al sostener que tal modelo permitiría alcanzar soluciones de una justicia y eficiencia muy superiores a las que permite el sistema actual, signado por la idea de prevención y el monopolio estatal de la persecución penal.

\section{V.A. Una pequeña idea de justicia}

La búsqueda de un concepto universal de justicia ha sido desde siempre una empresa infructuosa.

Quizá la dificultad radique en que, como lo reconocía Rawls, “[u]na concepción de la justicia no puede ser deducida de premisas evidentes o de condiciones sobre principios..." 54 . Más aún, la noción de "justicia" no solo no puede ser racionalmente deducida de principio superior alguno, sino que carece de contenido cognoscitivo, es decir, no designa ningún conjunto de propiedades susceptibles de ser consideradas verdaderas o falsas y, por ende, su validez no puede ser establecida a través de la razón ${ }^{55}$.

La idea de justicia no refiere sino a una valoración meramente subjetiva. Las personas catalogan como "justo" o "injusto" un determinado orden de cosas en la medida en que este se ajuste o no al conjunto de preferencias derivado de su escala de valores. Y esa escala individual de valores, por definición, no puede tener carácter universal ni justificación racional alguna, aun cuando algunos valores específicos sean compartidos por un conjunto significativo de personas.

No es casual, entonces, que el análisis económico preste escasa atención a la justicia de sus prescripciones normativas. Dada la imposibilidad de establecer un criterio universal de justicia, ha preferido recurrir a la idea de maximización de la riqueza social como principio rector del ordenamiento jurídico, la cual -tal como lo sostiene Posner- al depender de la exteriorización de las valoraciones subjetivas de los individuos expresada por su predisposición al pago para obtener ciertos bienes, parece un principio mucho más preciso para establecer una teoría de la justicia que los propuestos por el utilitarismo o la ética kantiana ${ }^{56}$.

El principio de maximización de la riqueza pareciera ser sencillo de aplicar cuando nos encontramos frente a transacciones libres y voluntarias, puesto que si dos personas

54 John Rawls. Teoría de la Justicia, segunda edición. María Dolores González (trad.), México DF, Fondo de Cultura Económica, 1995, p. 33.

55 Cfr. Carlos Nino. Introducción al análisis del Derecho, segunda edición, Buenos Aires, Astrea, 1998 , p. 363.

56 Cfr. Richard Posner. "Utilitarismo, economía y teoría del Derecho”, en Estudios Públicos, n. o 69, Santiago de Chile, Centro de Estudios Públicos, 1998, p. 234. 
deciden llevar a cabo cualquier tipo de intercambio, lo hacen en el entendimiento de que obtendrán una ganancia al adquirir algo que consideran más valioso que aquello de lo que se desprenden.

Sin embargo, cuando no nos encontramos frente a transacciones voluntarias, sino frente a transferencias forzosas de bienes como aquellas a las que se refieren las normas penales, el análisis económico neoclásico no parece una opción superadora del viejo utilitarismo. No existe, cuando no hay un mercado en el que se expliciten las preferencias individuales, un parámetro para efectuar la ponderación de las distintas valoraciones en pugna: no hay modo de establecer el "precio" del miedo de un conjunto de individuos a ser víctimas de un delito, el dado por la víctima a los bienes perdidos, o el valor subjetivo otorgado por el delincuente a su botín. En ausencia de transacciones reales, todo pronóstico respecto de la eficiencia de una norma es especulación más o menos infundada.

El problema que aqueja al análisis económico neoclásico en su aplicación al Derecho penal es el mismo que afecta a cualquier otro sistema ético-normativo que pretenda adoptar pautas generales de justicia o eficiencia aplicables a grandes agregados, pero disociadas de las acciones e intereses implicados en cada caso concreto. Al desconocer la subjetividad propia de ideas como justicia o riqueza, estos sistemas imponen a las personas soluciones que prescinden de considerar sus intereses reales.

Como alternativa a estas concepciones omnicomprensivas de justicia, propongo un sistema que no busque la consecución de ningún estado final a nivel de grandes agregados como la sociedad, sino que simplemente permita a los individuos buscar soluciones justas para cada caso concreto.

En tal sistema, la pena sería fijada, en la medida de lo posible, mediante un proceso de negociación entre víctima y victimario. De este modo, la pena perdería su propósito disuasivo, limitándose a la función de mera compensación o reparación a la víctima por el daño que ha sufrido.

Una concepción de la idea de justicia restringida a aquello que las partes involucradas en un conflicto estén dispuestas a aceptar voluntariamente es la única, a mi entender, verdaderamente compatible con el respeto a la libertad individual y la pluralidad de valores propia de una cosmovisión liberal.

Si aceptamos que existen tantas concepciones de la justicia como personas capaces de efectuar valoraciones, la única forma de establecer una pena justa será escuchar las demandas de castigo y/o reparación formuladas por la propia víctima de un delito, y tratar de conciliarlas con aquello que el victimario está dispuesto a aceptar como consecuencia del acto ilícito que ha llevado a cabo. Un modelo de justicia penal reparatoria que privilegie la adopción de soluciones consensuadas por sobre la imposición de penas establecidas en abstracto por un legislador ajeno al conflicto 
concreto tenderá a ser modelo justo, no por adecuarse mejor a alguna concepción universal de "justicia", sino por ser el único capaz de atender las preferencias de los individuos afectados en cada caso. No puedo en este sentido sino coincidir con lo expuesto por Bovino, quien señala:

... es necesario recordar que este mecanismo representa un reconocimiento del interés concreto de la víctima, razón por la cual sólo la víctima, en principio, es la persona idónea para evaluar la justicia de la reparación o del acuerdo. Así, aun cuando, en términos objetivos, la reparación no guarde proporcionalidad con el daño - por ejemplo, según las reglas resarcitorias del derecho civil-, el juez debe respetar el acuerdo si la víctima expresa su satisfacción ${ }^{57}$.

Este modelo de justicia penal reparatoria tendría, además, la virtud de permitir una asignación más eficiente de recursos en la sociedad, aunque partiendo de una noción de eficiencia algo distinta a la adoptada por el análisis económico neoclásico, puesto que no se identifica con la maximización de la riqueza de la sociedad, sino con la maximización del bienestar de las personas individualmente consideradas. La eficiencia, en estos términos, consiste en que cada quien pueda satisfacer la mayor cantidad de necesidades consideradas prioritarias de acuerdo a su propia escala de valore $^{58}$. Desde esta perspectiva, el sistema penal más eficiente será aquel que permita arribar a un mayor número de soluciones consensuadas, que son la única prueba palpable de la existencia de una efectiva maximización de la riqueza.

Podemos concluir entonces que un sistema que abandona la pretensión de establecer pautas universales de justicia y eficiencia, permitiendo y estimulando en cambio que las partes afectadas arriben a soluciones consensuadas en cada caso particular será, paradójicamente, capaz de satisfacer más adecuadamente las exigencias de justicia y eficiencia. La suma de las pequeñas concepciones individuales respecto de lo justo y lo eficiente parece ser una mejor vía para afianzar tales valores que la adopción de grandes concepciones omnicomprensivas salidas de la mente de algún filósofo o economista particularmente persuasivo.

Bajo estas premisas, el proceso penal no se diferenciaría sustancialmente del civil, excepto en que el primero, además de la reparación pecuniaria o moral del daño, contemplaría la posibilidad de establecer medidas de seguridad a favor del actor o de terceros, inclusive aquellas restrictivas de la libertad del demandado. En realidad, bajo un modelo de justicia penal reparatoria, la única diferencia relevante entre el

57 Alberto Bovino. Ob. cit., p. 112.

58 Cfr. Juan Carlos Cachanosky. "Eficiencia económica y sistemas jurídicos", Revista de la Facultad de Derecho, Año IV, n. 8 (octubre de 1994), Guatemala, Universidad Francisco Marroquín, 1994, p. 27. 
proceso civil y el penal sería el más amplio objeto de la demanda que se admitiría en el segundo.

\section{V.B. Pautas para un modelo de justicia penal reparatoria}

La idea de un proceso penal contradictorio en el cual se enfrentan directamente la víctima del delito y su agresor sin otro objeto que dirimir la reparación -material y/o simbólica- del daño, y en el que la intervención estatal se limita al rol de juzgador imparcial y a asegurar el cumplimiento de la sentencia, registra numerosos antecedentes históricos e incluso subyace a varias reformas legislativas contemporáneas ${ }^{59}$.

Entiendo que un modelo de Derecho penal compatible con las ideas morales y económicas propias de la tradición liberal, debería profundizar esta tendencia de privatización de los procesos penales -entendiendo como tal al paulatino reemplazo de la pena por la reparación y la introducción de la composición privada como forma de resolución de los conflictos ${ }^{60}{ }^{6}$, hasta convertirla en la norma y no, como hasta hoy, una mera excepción dentro de un sistema signado por el monopolio estatal de la persecución penal.

59 Entre los ejemplos de sistemas jurídicos en que prima la idea de privatización de la acción penal, quizás el más paradigmático sea el de los pueblos germánicos de la Alta Edad Media, en el cual para iniciar un proceso resultaba necesario que la víctima demostrase haber sufrido un daño e identificase a su autor, el objeto del juicio no estaba determinado por la autoridad sino por la demanda, y las partes intervenían en un pie de igualdad (Cfr. AlberTo Bovino; "Un modelo nada primitivo: el enjuiciamiento penal de la Alta Edad Media", en AA.Vv., La cultura penal. Homenaje al profesor Edmundo S. Hendler. Gabriel Anitua e Ignacio Tedesco [Comps.], Buenos Aires, Del Puerto, 2009, pp. 176 y 178). También en la antigua Roma, en la Inglaterra medieval, en los Estados Unidos de la época colonial e incluso en Japón hasta mediados del siglo xx, pueden encontrarse ejemplos de sistemas penales en los que la víctima adquiría un rol preponderante y, en mayor o menor medida, se asemejaban al moderno derecho de daños (Cfr. RiCARdo MANUEl RojAS. Ob. cit., pp. 144 a 155). En la actualidad, numerosas legislaciones procesales reconocen a las víctimas el derecho a participar activamente en el proceso e incluso instar a su finalización si han sido adecuadamente resarcidas de los daños padecidos como consecuencia del delito. Así, entre otros, el Código Procesal Penal de Costa Rica contempla en su art. 30, como causales de extinción de la acción penal, la "reparación integral a entera satisfacción de la víctima" y la conciliación. Esta última procede en los delitos de menor significación, y según el art. 36 debe ser procurada por el tribunal. En Chile, el Código Procesal Penal también contempla, en sus arts. 241 y 242, que se ponga fin al proceso si las partes arriban a un acuerdo reparatorio, aunque tales acuerdos "sólo podrán referirse a hechos investigados que afectaren bienes jurídicos disponibles de carácter patrimonial, consistieren en lesiones menos graves o constituyeren delitos culposos". El Código Procesal Penal peruano del año 2004, en su art. $2^{\circ}$, admite la posibilidad de que el Fiscal se abstenga de ejercitar la acción penal si el imputado repara los daños ocasionados por el delito o llega a un acuerdo con la víctima en tal sentido.

60 Cfr. Alejandra Alliaud. "Los métodos alternativos de resolución de conflictos penales en el Derecho Comparado”, en AA.VV., La cultura penal. Homenaje al profesor Edmundo S. Hendler. GABRIEL Anitua e Ignacio Tedesco (Comps.), Buenos Aires, Del Puerto, 2009, p. 19. 
Dentro de este esquema, el proceso judicial destinado a resolver los conflictos derivados de un delito debería asimilarse a cualquier acción por daños y perjuicios. Solo por excepción, frente a casos particularmente graves en los que no se puede alcanzar un acuerdo entre las partes, los jueces deberían estar habilitados a imponer penas con los límites y garantías para el imputado propios del actual Derecho penal.

Siguiendo esta idea, deberían reducirse al mínimo los procesos penales iniciados de oficio por la autoridad pública. El inicio de la acción penal debería depender, principalmente, del impulso de la víctima o de quien pueda invocar un interés legítimo en la investigación del delito. Respecto del contenido de la demanda que daría inicio al proceso, coincido con Rojas en que:

Siguiendo los principios del procedimiento civil, la demanda debería contener una descripción circunstanciada del hecho, del perjuicio sufrido, la responsabilidad del demandado y su pretensión. Esta demanda marcaría los límites del juicio y de la pretensión del demandante, y en consecuencia marcaría los límites para la intervención del juez ${ }^{61}$.

Dentro de este esquema, la víctima podría solicitar tanto una reparación económica como moral (vgr. el pedido de que el demandado haga público su arrepentimiento), e inclusive prestaciones no monetarias, como la realización de trabajos en su favor. También podría contemplarse el pedido de medidas coercitivas de naturaleza esencialmente penal, como la restricción de la libertad ambulatoria del demandado, en caso de que el damnificado las considerase necesarias para su seguridad o para la protección de terceros.

En líneas generales, no deberían imponerse mayores restricciones al contenido de la demanda. Este aspecto es particularmente relevante, puesto que implicaría derogar el clásico sistema de penas tasadas, establecidas por un legislador ajeno al conflicto, para dar lugar a un mecanismo que permita al propio damnificado expresar cuál es el valor que asigna a los bienes que han sido afectados por el delito.

Una vez determinada la pretensión del damnificado e identificado el demandado, debería abrirse una etapa de negociación en la cual las partes busquen arribar a una resolución consensuada del conflicto. El papel del juez en esta etapa preliminar debería limitarse a mediar entre las partes, posibilitando la adopción de soluciones de compromiso, homologando todo acuerdo conciliatorio, cualquiera sea su contenido, a menos que se demuestre que ha mediado fraude, violencia, intimidación o abuso de una situación de desigualdad.

61 Ricardo Manuel Rojas. Ob. cit., p. 181. 
Hasta aquí, el sistema que planteo se correspondería con lo propuesto por Hulsman, cuando explicaba:

En todos los casos habría que devolver a las personas implicadas el manejo de sus conflictos. El análisis que ellas hacen del acto no deseable y de sus intereses reales debería ser el punto de partida necesario de la solución que se busca. La relación "cara a cara" debería ser siempre posible, ya que las explicaciones mutuas, el intercambio de las experiencias vividas y, si es necesario, la presencia activa de personas psicológicamente próximas, pueden conducir en el "cara a cara" a soluciones realistas para el futuro.

Nadie podrá decir de antemano cuál es la clave más adecuada para resolver una situación conflictiva, y la ley deberá abstenerse de imponer un tipo de reacción uniforme y de definir las situaciones respecto de las cuales ese tipo de reacción deba aplicarse automáticamente ${ }^{62}$.

En caso de que las partes no lleguen a un acuerdo, el proceso continuaría como cualquier proceso civil. De comprobarse la existencia del daño alegado por el actor y la responsabilidad del demandado, el juez dictaría sentencia graduando la forma y extensión del resarcimiento de acuerdo con la gravedad del perjuicio sufrido por la víctima, el grado de culpabilidad del acusado y sus posibilidades objetivas de reparación.

En cuanto a las medidas restrictivas de la libertad del demandado, el juez solo debería poder imponerlas con carácter excepcional, en aquellos casos de crímenes dolosos violentos en los que existieran fundados motivos para suponer que la libertad del acusado implicaría un riesgo cierto para la seguridad de la víctima o de terceros. Al respecto sostiene Rojas:

... sólo se puede justificar la privación de la libertad ambulatoria del criminal, cuando tiene por finalidad proteger concretamente a la víctima o eventualmente a otras personas que demuestren un interés directo, solamente en el caso en que el victimario haya demostrado con hechos concretos su peligrosidad, su desprecio a los derechos ajenos o su especial animosidad hacia la víctima. Debería ser, por lo tanto, un modo de sanción justificada en sí misma, destinada directamente a proteger ciertos derechos de la víctima o terceros interesados, y no una medida indirecta para lograr un resarcimiento económico ${ }^{63}$.

62 Louk Hulsman y JaCQueline Bernat De Celis. Sistema penal y seguridad ciudadana: hacia una alternativa, Barcelona, Ariel, 1984, p. 91.

63 Ricardo Manuel Rojas. Ob. cit., p. 197. 
La existencia de este espacio irreductible de coerción es lo que, aun en el esquema propuesto, justifica la subsistencia de un Derecho penal, residual, cuyos caracteres esbozaré un poco más adelante.

Antes de introducirme en este último tema, deseo referirme a dos aspectos controvertidos que presentaría un sistema de justicia penal reparatoria: la legitimación procesal para demandar y la asignación de los costos de investigación y producción de pruebas.

La cuestión de la legitimación procesal resulta medular al diseño de un sistema de justicia penal reparatoria justo y eficiente, puesto que, como vimos, tales exigencias solo pueden alcanzarse atendiendo a la satisfacción de los intereses de la víctima (y, en lo posible, procurando el consentimiento del acusado). Definir quién reviste la calidad de víctima, entonces, es el primer paso lógico para el desarrollo del modelo.

Dado que las valoraciones son forzosamente subjetivas, la única persona idónea para decidir si una determinada sanción o resarcimiento compensan el valor de los bienes afectados por el delito, es el propio titular de esos bienes. Por ello, consideraremos primariamente como víctima legitimada para demandar, al titular de aquellos bienes (materiales o inmateriales) que hayan sido menoscabados por la acción del acusado. La sustitución del criterio de la víctima por el de otras personas -aun sus familiares o representantes legales-, implicaría imponerle a aquella una solución que no le pertenece y que no puede ser completamente justa ni eficiente por cuanto tales calificaciones se corresponden con valoraciones que son, por definición, intransferibles.

Sin embargo, existen algunos supuestos en los cuales la legitimación activa debería extenderse a otras personas, aunque no hayan sido directamente afectadas por el acontecimiento dañoso.

El primer y más obvio caso es aquel en que la víctima no puede intervenir en el proceso por sus propios medios, por tratarse de un incapaz o por haber fallecido. Ante estas situaciones, la legitimación debería ser asignada a sus representantes legales o herederos quienes, aun cuando no puedan sustituir perfectamente la valoración de los bienes atacados por el delito que haría la propia víctima, son las personas que más aproximadamente podrían estimarla. Por otra parte, estos sujetos, así como algunos allegados muy cercanos a la víctima, podrían tener un interés propio digno de tutela jurídica, que ameritaría también el reconocimiento de una legitimación subsidiaria aun si el damnificado puede actuar por sí mismo (por ejemplo, en el caso del padre que ha sufrido grandes padecimientos al acompañar la convalecencia de su hijo gravemente lesionado).

Un segundo caso en el que se podría ampliar la legitimación activa se presenta cuando el daño comprende a un gran número de personas, pero la afectación es individualmente poco significativa para cada una de ellas. Igualmente, en estos supuestos siempre resultaría exigible la demostración de un perjuicio concreto -aunque no 
sea mínimo- por parte de quien pretende que se le reconozca legitimación procesal, puesto que un derecho penal reparatorio de cuño liberal no podría admitir la persecución de delitos sin víctimas, fundada solo en el rechazo que algunas personas sienten por determinados actos ${ }^{64}$. A lo que apunto, básicamente, es a los delitos que afectan intereses difusos, supuestos en los existen costos de transacción prohibitivos para la mayoría de los afectados que podrían actuar en defensa de un derecho propio.

Imaginemos que un inescrupuloso personaje decide iniciar una campaña pública recolectando donaciones para las víctimas de una inundación. Las donaciones se instrumentan a través de mensajes de texto, cuyo costo individual no supera los cinco pesos. Una vez reunida una cantidad suficiente de dinero, el organizador de la colecta huye con los fondos recaudados, que nunca llegan a los donatarios. Está claro que en este caso ha existido un accionar fraudulento, por el cual miles de engañados donantes han visto menoscabado su patrimonio. Sin embargo, es poco probable que alguno de ellos asuma los costos para llevar el caso a los tribunales, dado que el perjuicio sufrido es individualmente insignificante.

En esta y otras situaciones análogas podríamos arribar a resultados ineficientes, tal como lo sería permitir el enriquecimiento impune de quien ha causado un daño patrimonial a gran número de personas, siempre que el daño individual sea lo suficientemente pequeño como para desalentar a cada damnificado a iniciar acciones judiciales. El reconocimiento de legitimación procesal a organizaciones que representen los derechos de las víctimas sería una solución para superar el problema de los costos de transacción prohibitivos en este tipo de casos.

El último supuesto en que existirían razones válidas para una ampliación de la legitimación procesal a personas que no han sido directamente afectadas por el delito, es cuando existen sujetos que tienen fundados motivos para suponer que se encuentran en peligro de ser víctimas de sucesos similares. Rojas recurre al ejemplo de la vecina de una víctima de violación, que puede estar interesada en solicitar la prohibición al imputado de circular por las inmediaciones de su casa ${ }^{65}$. Podemos imaginar muchos otros supuestos de personas con un legítimo interés para solicitar medidas judiciales tendientes a la protección de su seguridad. El Derecho debería permitir que estas personas, actuando individual o colectivamente, puedan obtener una respuesta que contribuya a dispersar su temor a ser víctimas de un delito, al menos cuando este es suficientemente fundado.

64 El caso paradigmático que tengo en mente es el del tráfico de drogas, actividad que no debería ser objeto de una respuesta punitiva en la medida en que el supuesto daño consiste en una transacción voluntariamente aceptada por las partes intervinientes. El hecho de que algunas personas consideren pernicioso e incluso peligroso que otras utilicen drogas no es motivo suficiente para reconocerles legitimidad procesal en contra de la voluntad expresa de los propios consumidores. 
Finalmente, dejando de lado la cuestión de la legitimación procesal, debo sucintamente referirme al problema de la asignación de los costos de investigación del delito, identificación de su autor y juzgamiento. Todos estos actos implican gastos que alguien debe afrontar. En un proceso penal "privatizado” la pregunta es: ¿quién lo paga?

Para Rojas, la respuesta es que la propia víctima debería asumir esos costos:

Al eliminarse el carácter público del proceso desaparecería la función de investigador que hoy cumple el gobierno, tarea que pasaría a ser responsabilidad de los demandantes ${ }^{66}$.

Dicho autor intenta eludir la crítica obvia de que una regla de tal naturaleza dejaría desprotegidas a las personas más pobres, planteando la posibilidad de que existan empresas especializadas en comprar las acciones legales de esos individuos, asumiendo los respectivos costos de investigación ${ }^{67}$. El argumento no me resulta demasiado convincente, dado que existen casos en los cuales el valor de mercado de los bienes afectados por el delito es insignificante pero subjetivamente muy alto para la víctima, o en los que el damnificado solo busca obtener una reparación moral o una medida de protección sin contenido económico. En ninguno de estos supuestos existiría una empresa dispuesta a comprar la acción y asumir los costos de investigación.

Ilustremos el problema con un nuevo ejemplo.

Pensemos en un hombre humilde que utiliza una vieja bicicleta para ir a trabajar. Un día un joven le roba la bicicleta y la vende por \$ 100 para comprar drogas. La bicicleta, para la víctima, vale mucho más que \$100 -puesto que la necesita para llegar a su trabajo y no puede comprar una nueva-. El hombre no está interesado en el encarcelamiento del ladrón: lo único que pretende es solucionar su problema de transporte. Por su parte el joven, si es atrapado, quizás esté dispuesto a reconocer su falta, pedir perdón, y entregar a la víctima su propia bicicleta, a cambio de evitar una sanción más severa. Es decir, un acuerdo es posible, si no fuera porque la víctima carece de los medios para identificar al autor del robo y ninguna empresa estaría dispuesta a comprar una acción cuyo único beneficio potencial es obtener el precio de una bicicleta destartalada. En este ejemplo, un conflicto no se soluciona porque nadie está dispuesto a afrontar el gasto necesario para poner a las partes frente a frente. Una repetición de este tipo de situaciones, podría representar un costo social significativo, dado por el descontento de la comunidad frente a un sistema legal que no brinda respuestas a sus problemas.

66 Ibídem, p. 179.

67 Cfr. Ibídem. 
La única solución a la situación planteada es que alguien subsidie a la víctima los costos de investigación. Ese alguien no tiene que ser necesariamente el Estado. Bien podría ser también alguna institución privada de bien público que asista a las víctimas de delitos que carecen de medios económicos. Pero en el caso de que tales instituciones no existan, no veo otra forma de asegurar la justicia que cargar al Estado los costos de investigación y juzgamiento, aunque no sea con carácter subsidiaria. Es claro que, aunque los contribuyentes terminen afrontando con sus impuestos el costo del sistema penal, más costoso aún resultaría sostener un orden jurídico que la mayoría de las personas consideraría injusto.

\section{V.C. Razones para un Derecho penal residual}

La propuesta privatizadora de los conflictos penales planteada en los párrafos anteriores no es completamente abolicionista, por cuanto deja espacio a un sistema residual regido por los principios tradicionales del Derecho penal.

Existen quienes suponen que, una vez abolido el monopolio estatal de la persecución penal y devuelta a las partes la facultad de resolver el conflicto, las garantías propias del Derecho penal liberal perderían su razón de ser. Se sostiene así que, si la potestad jurisdiccional se abre solo ante la solicitud de un damnificado que debe probar el perjuicio que ha sufrido, el hecho de que el daño pueda ser medido y constituya el límite de la demanda resulta garantía suficiente de los derechos del imputado frente a pretensiones desmedidas o arbitrarias:

... si el Estado no impusiera conductas a los individuos bajo la amenaza penal, si las acciones judiciales fuesen devueltas a los particulares y las sentencias tuviesen por finalidad responder a pretensiones resarcitorias y de protección de los derechos de las víctimas, pienso que el principio de legalidad no sería necesario, y las posibilidades de autoritarismo y corrupción judicial disminuirían ${ }^{68}$.

Por mi parte, considero que tal postura resulta contradictoria con la teoría subjetiva del valor en la cual pretende sustentarse y, lo que es peor, subestima el peligro que implica un poder punitivo potencialmente ilimitado, ya sea que se encuentre en manos de particulares o del Estado.

Rojas, al referirse a la mensurabilidad del daño invocado por la víctima, soslaya que, al ser las valoraciones por definición subjetivas, el damnificado puede otorgar a ese daño cualquier valor imaginable, por lo que no habría en rigor límite alguno al potencial poder punitivo privatizado.

68 Ibídem, p. 86. 
Como ejemplo, tomemos el valor de cualquier bien, como podría ser un plato de fideos. En la mayoría de los casos, nadie estaría interesado en iniciar una acción judicial si el vecino entra a su casa y se come los fideos que se encontraban servidos en la mesa. Pero, en algún caso excepcional, el plato de fideos puede tener un elevado valor subjetivo (vgr., porque lo preparó la abuela de la víctima inmediatamente antes de morir, porque el dueño de casa hace días que no come, o porque es el último plato de pastas sobre la faz de la Tierra). En cualquiera de esos casos -extremos pero no imposibles de imaginar- el damnificado podría sentirse gravemente perjudicado por la pérdida de sus fideos y solicitar que se encarcele a quien osó comerlos sin su permiso. Ergo, reconocer la intrínseca subjetividad y mutabilidad de las valoraciones, implica aceptar que la medida del daño no puede a priori constituir un límite suficiente a la facultad de imponer sanciones.

En definitiva, si se admite que la víctima solicite, como medio de protección para su persona o como forma de reparación moral, que se encarcele al demandado, se le prohíba transitar por ciertos lugares o se restrinja su libertad de cualquier otra forma, suponer que tal facultad no debe ser limitada de algún modo implica desconocer las razones mismas que dieron origen al Derecho penal liberal.

Para ilustrar este punto volvamos al ejemplo de los fideos y supongamos que el damnificado, emocionalmente afectado por haber perdido la posibilidad de degustar el último plato de pastas preparado por su abuela, pide a un tribunal que se encarcele de por vida a su angurriento vecino, argumentando que de otro modo jamás tendrá la seguridad de que la comida no le será arrebatada de la mesa. Por algún motivo que desconocemos, el tribunal hace lugar al pedido y dispone la inmediata detención del demandado. Quizá el caso hipotético pueda parecer exagerado, pero lamentablemente la historia judicial de la humanidad registra sobrados ejemplos de penas absurdas y desproporcionadas.

Esta posibilidad de sentencias desproporcionadas obligaría a cada individuo a tomar una enorme cantidad de precauciones legales antes de llevar a cabo cualquier acción, que por su costo tornarían antieconómicas a la mayoría de las actividades humanas. Abrir la posibilidad de que se apliquen penas privativas de libertad por cualquier tipo de daños no consentidos por la víctima implicaría, como señala Nozick, incorporar un importante factor de inseguridad a la vida de las personas, que jamás podrían estar seguras de no ser sancionadas por cualquier suceso, incluso de carácter accidental ${ }^{69}$.

Parece claro que, aun cuando el poder coactivo del Estado se ponga al exclusivo servicio de las víctimas, ese poder precisa ser limitado de algún modo. Esa función de límite sería desempeñada por un Derecho penal residual que garantice la vigencia de los principios de legalidad, culpabilidad, proporcionalidad, presunción de inocen- 
cia y debido proceso, en aquellos casos en que resultara ineludible la imposición de medidas restrictivas de la libertad del demandado. Como lo destaca Ferrajoli, ese es precisamente el propósito del Derecho penal moderno:

... resulta evidente el fin justificador del derecho penal como sistema racional de minimización de la violencia y el arbitrio punitivo y de maximización de la libertad y la seguridad de los ciudadanos. La idea de que un sistema racional de penas ciertamente aflictivas tiene el fin de minimizar las penas informales y más aflictivas que se producirían de otro modo puede parecer una paradoja sólo a quienes hayan olvidado el carácter "artificial" del derecho penal hasta un punto tal como para considerarlo poco menos que un fenómeno natural. La paradoja, en realidad, está más bien en las doctrinas abolicionistas de inspiración progresista, habida cuenta de que el derecho penal representa el máximo esfuerzo llevado a cabo para minimizar y disciplinar el arbitrio y el abuso punitivo. El abolicionismo penal más allá de sus intenciones libertarias y humanitarias se configura por todo ello como una utopía regresiva que, bajo presupuestos ilusorios de una sociedad buena o de un estado bueno, presenta modelos en realidad desregulados o autorregulados de vigilancia y/o castigo respecto a los cuales es el derecho penal -con su complejo, difícil y precario sistema de garantías- el que constituye, histórica y axiológicamente, una alternativa progresista ${ }^{70}$.

La crítica de Ferrajoli apunta acertadamente a una de las mayores falencias del abolicionismo, cual es su desinterés en contemplar medios para limitar el poder coactivo devuelto a los particulares. Como lo vengo sosteniendo, un poder punitivo incontrolado es siempre peligroso independientemente de quien lo detente y, ante esa amenaza, la existencia de un Derecho penal residual destinado a limitar el empleo de respuestas violentas a los conflictos cuando las soluciones consensuales devienen imposibles resulta, al parecer, la menos mala de las alternativas disponibles.

Dentro del esquema de justicia penal reparatoria que planteo, los tradicionales principios del Derecho penal seguirían teniendo por objeto, entonces, delimitar el universo de casos en los cuales podrían ser aplicadas medidas restrictivas de la libertad (legalidad), la intensidad admisible las sanciones (proporcionalidad) ${ }^{71}$ y las

70 Luigi FerRajoli. Ob. cit., pp. 340 y 341.

71 El problema de la proporcionalidad de la pena es sumamente complejo y, a decir verdad, la ciencia económica ofrece escasas herramientas para resolverlo satisfactoriamente. Descartada la hipótesis sostenida por la economía neoclásica, según la cual sería posible graduar las penas teniendo en cuenta su efecto disuasivo, el costo que implica su imposición, y el costo social de los delitos que se busca disuadir, la única pena proporcional y eficiente en cada caso concreto sería aquella que acuerden libremente las partes. Ahora bien, ante la imposibilidad de tal acuerdo, cualquier límite que se imponga como pena máxima para cada tipo de delito -aun siendo necesario por razones de seguridad 
condiciones exigibles para hacerlas efectivas (culpabilidad, presunción de inocencia, debido proceso).

En particular, dado que el sistema de justicia penal reparatoria no aboliría completamente la pena de prisión, y teniendo en cuenta que tal sanción es cualitativamente la de mayor gravedad, las restricciones más intensas deberían estar dirigidas a limitar su aplicación. Salvo que el acusado preste su consentimiento a la aplicación de medidas limitativas de su propia libertad ambulatoria, la norma debería ser la prohibición de la pena de prisión. La pregunta obvia es: ¿cuáles deberían ser las excepciones a ese principio?

La respuesta es que las penas privativas de la libertad deberían reservarse solo a aquellos casos en los que la víctima o un tercero puedan acreditar -con cierto grado de verosimilitud- que resultan necesarias para resguardar su vida o su integridad física, y solo en la medida en que esa protección no pueda razonablemente alcanzarse por medios menos gravosos para el imputado, como lo podrían ser medidas de vigilancia policial, la prohibición de transitar por ciertos lugares, etc. En definitiva, solo el riesgo cierto para la vida o la integridad física de la propia víctima o de terceros justificaría la aplicación de un remedio extremo, como lo es la pena de prisión.

Por cierto, los casos de delitos violentos que justificarían la aplicación de medidas restrictivas de la libertad no son estadísticamente los más numerosos, pero son sin embargo suficientes como para reforzar la necesidad de un Derecho penal residual que ponga límites al poder coercitivo y asegure el respeto a los derechos y garantías de los imputados. Siendo utópico renunciar a las medidas coercitivas contra los autores de hechos violentos tales como el homicidio, la violación o las lesiones corporales graves, resulta imperioso al menos limitar ese poder punitivo de modo de evitar su uso desmedido o arbitrario.

Considero que no corresponde aquí seguir ahondando sobre la razones que justifican el mantenimiento de los tradicionales principios y garantías que rigen el Derecho penal liberal, sino simplemente dejar sentado que los límites al poder punitivo resultan necesarios aun cuando la titularidad de la acción penal se devuelva a los sujetos damnificados por el delito y la pena de prisión se restrinja a un número relativamente reducido de casos -básicamente, aquellos caracterizados por el despliegue de violencia física contra las víctimas-. En tanto el poder de infringir deliberadamente un daño a la persona signada como responsable de un delito subsista (lo cual es de esperar que siga siendo así en tanto sigan existiendo las humanas necesidades de obtener seguridad, reparación o venganza), el Derecho penal seguirá siendo necesario no para justificar ese poder punitivo, sino para imponerle un límite racional.

jurídica- será arbitrario en el sentido de que no representará una solución plenamente eficiente para el caso juzgado. 


\section{CONCLUSIONES}

Después de haber analizado los presupuestos básicos del análisis económico neoclásico del Derecho penal, criticado algunas de sus falencias teóricas y axiológicas y propuesto un modelo alternativo de justicia penal que entiendo simultáneamente compatible con las enseñanzas de la economía y las prescripciones jurídico-morales del liberalismo político, creo que ha llegado el momento de extraer algunas conclusiones y pasar en limpio los principales conceptos.

Lo primero que parece relevante destacar es que la idea ultrasimplificada del maximizador racional, en la cual se asienta el análisis económico neoclásico del Derecho penal, implica una representación demasiado pobre de la realidad como para explicar satisfactoriamente las causas de la criminalidad. La mente humana es infinitamente más compleja que la representación del modelo neoclásico y, si bien el análisis costo-beneficio realizado en función de las expectativas de sanción puede en algunos casos ser un factor motivacional relevante, lo cierto es que las razones por las cuales una persona causa deliberadamente un daño a otra son inabarcables para cualquier observador, e incluyen cuestiones tan variadas como las escalas de valores personales, el contexto social, las historias de vida, los vínculos familiares, las alteraciones psíquicas, etc. De allí que la idea de que un técnico munido de las herramientas conceptuales del análisis económico pueda resultar capaz de disponer los incentivos necesarios para disuadir la realización de toda conducta socialmente indeseable, resulta poco menos que una fantasía irrealizable.

Pero el modelo neoclásico falla no solo por suponer que las conductas humanas pueden ser deliberadamente modificadas manipulando un par de variables, sino también por plantearse un objetivo utópico. Aun cuando fuera posible regular fácilmente el número de conductas delictivas modificando las penas esperadas, ¿cómo haríamos para saber que el estado de cosas así alcanzado es socialmente eficiente o siquiera deseable?

El objetivo de equiparar el costo social del delito con el costo social de su prevención es inviable, porque ni lo uno ni lo otro es susceptible de ser cuantificado. Hemos visto que el mentado costo social del delito sería algo así como la suma del daño efectivamente sufrido por la víctima y el temor del resto de los integrantes de la sociedad a padecer hechos similares. Ambos son conceptos enteramente subjetivos y variables. El valor que otorga cada víctima a los bienes afectados por el delito es una cuestión enteramente personal, que solo puede ser conocida a ciencia cierta si ella misma fórmula un pedido concreto de reparación. El miedo es una vara aún más caprichosa para cuantificar el costo social: no solo no existe una unidad para medirlo, sino que ni siquiera suele responder a la existencia de una concreta fuente de peligro para la persona que lo vivencia. 
La utopía del análisis económico neoclásico del sistema penal se torna además axiológicamente peligrosa en tanto contribuye a socavar algunos principios elementales del Derecho penal liberal, que hacen a la protección de la vida, la libertad y la dignidad del individuo. En tanto formulación sofisticada del tradicional utilitarismo, el AED lleva casi siempre implícita la tentación de sacrificar al individuo en aras del supuesto interés de la mayoría. Bajo la óptica de la economía neoclásica, principios tan esenciales a la protección del individuo frente a la amenaza totalitaria del Estado como el de culpabilidad, la presunción de inocencia, la aplicación de la ley más benigna o el debido proceso están siempre sujetos a la condición de que no se demuestre que su abolición conllevaría un incremento de la utilidad social.

Con todo, las distintas variantes del Análisis Económico del Derecho penal tienen a su favor poner de manifiesto un punto usualmente pasado por alto por los juristas: que toda decisión de política criminal implica una asignación de recursos y un efecto sobre la realidad que es preciso tener en cuenta antes de legislar. Los abogados tendemos a pensar que las normas tienen un efecto mágico sobre la realidad, y que bastaría prohibir determinada conducta para que esta no se lleve a cabo. La utilización de las herramientas de la economía nos muestra que, por el contrario, las normas a lo sumo pueden modificar los incentivos que tienen las personas para actuar, pero por sí mismas no bastan para inducir determinados comportamientos. El razonamiento económico nos recuerda que hay que ser cuidadosos al momento de imponer reglas legales, puesto que si no se analizan suficientemente los incentivos que generan, corremos el riesgo de que terminen produciendo efectos diametralmente opuestos a los deseados.

La pregunta que queda en pie cuando analizamos el sistema penal es, entonces, al servicio de quién deben estar los incentivos que generan las normas y quién debe ser el encargado de formular la política criminal.

Mi respuesta es que las normas deben servir a la resolución de los conflictos reales que padecen las personas de carne y hueso, en lugar de estar orientadas hacia nociones abstractas como la justicia o la eficiencia. Esta opción, que pareciera ser una cuestión casi semántica, implica sin embargo un giro copernicano en la concepción del Derecho penal.

En primer lugar, implicaría poner a la víctima en el centro de la atención, devolviéndole todas las facultades que el monopolio estatal de la persecución penal le ha expropiado: la de iniciar el proceso, impulsarlo y decidir cuándo ponerle fin. Esto a su vez traería aparejada la completa resignificación de la noción de pena, que dejaría de ser un medio de castigo o una forma de intimidación dirigida al conjunto de la sociedad, para dar lugar a diversas formas de reparación del daño o a específicas medidas de seguridad concebidas en el interés de las víctimas concretas o potenciales. 
Por otro lado, la implementación de un modelo de justicia penal reparatoria sería probablemente una forma mucho más eficiente y racional de afrontar el problema de la delincuencia. El análisis económico neoclásico propone un modelo verdaderamente irracional de encarar ese problema, en el que el apego a una falsa certeza respecto de las causas del delito lleva a un círculo vicioso en el que el fracaso de la pena termina, paradójicamente, justificando su endurecimiento. El modelo que propongo, por el contrario, lleva implícito un ejercicio de humildad, que es la base de la auténtica racionalidad económica: nuestra ignorancia respecto de las circunstancias que llevan a cada individuo concreto a delinquir, y respecto de las expectativas de castigo o reparación que tiene cada víctima en particular.

Este reconocimiento de la propia ignorancia es lo que impone dejar la solución del conflicto a los sujetos más aptos para resolverlo, que no son otros que aquellos enfrentados en cada caso particular. Solo ellos pueden saber cuánto valoran lo que han perdido o cuánto están dispuestos a ofrecer para reparar un daño. Solo ellos, en rigor, pueden alcanzar una solución justa y eficiente para cada caso. Resulta casi paradójico que, además, de este modo probablemente se alcance una disuasión de las conductas socialmente consideradas disvaliosas mucho más eficiente de la que podría obtenerse a través del monopolio estatal de la coacción penal.

Dentro de este esquema, el Derecho penal que hoy conocemos tiene reservado un lugar residual pero no por ello menos importante: el de proteger a las personas de acusaciones injustas, de la arbitrariedad y del castigo desmedido. La pena volvería a ocupar, realmente, el lugar de ultima ratio del ordenamiento jurídico. El único lugar que, por cierto, puede tener en una sociedad genuinamente democrática y respetuosa de los derechos individuales.

\section{BIBLIOGRAFÍA}

Alliaud, Alejandra. "Los métodos alternativos de resolución de conflictos penales en el Derecho Comparado", en AA.vV., La cultura penal. Homenaje al profesor Edmundo S. Hendler. Gabriel Anitua e Ignacio Tedesco (Comps.), Buenos Aires, Del Puerto, 2009, p.

Avio, Kenneth. "The economics of prisons", en AA.VV., Encyclopedia of Law and Economics. Volume V. The Economics of Crime and Litigation. BoudEWIJN BouCKAERT, Gerrit De Geest (eds.), Cheltenham, Edward Elgar, 2000, p. 395.

Beccaria, Cesare. De los delitos y de las penas. Antonio Bonanno (trad.), Buenos Aires, Losada, 2004, p. 48. 
BECKER, GARY. "Crime and punishment: an economic approach", Journal of Political Economy, Vol. 76, n. ${ }^{\circ}$ 2, Marzo/Abril 1968, Chicago, University of Chicago, 1968, p. 170.

Benegas Lynch, Alberto (H). "Bienes públicos, externalidades y los free-riders: el argumento reconsiderado", Libertas, n. 28 (mayo 1998), Buenos Aires, ESEADE, 1998, p. 201.

Bovino, AlBerto. "Un modelo nada primitivo: el enjuiciamiento penal de la Alta Edad Media", en AA.Vv., La cultura penal. Homenaje al profesor Edmundo S. Hendler. Gabriel Anitua e Ignacio Tedesco [Comps.], Buenos Aires, Del Puerto, 2009, pp. 176 y 178).

Bovino, Alberto. Principios políticos del procedimiento penal, Buenos Aires, Del Puerto, 2009, p. 6.

Cachanosky, Juan Carlos. "Eficiencia económica y sistemas jurídicos”, Revista de la Facultad de Derecho, Año IV, n. 8 (octubre de 1994), Guatemala, Universidad Francisco Marroquín, 1994, p. 27.

Christie, NiLs. La industria del control del delito. Sara Costa (trad.), Buenos Aires, Del Puerto, 1993, p. 31.

Cooter, Robert y Ulen, Thomas. Derecho y economía. Eduardo Suárez (trad.), México D.F., Fondo de Cultura Económica, 1998, p. 564.

COWEn, Tyler. "Bienes públicos y externalidades", en AA.VV., Enciclopedia Fortune de economía. David Henderson (comp.), Barcelona, Folio, 1998, p. 20.

Del Río, Marco Antonio. "Nuevos rumbos de la criminología”, Laissez - Faire, n. 15, septiembre 2001, Guatemala, Universidad Francisco Marroquín, 2001, pp. 34-35.

EIDE, ERLING. "Economics of criminal behavior", en AA.VV., Encyclopedia of Law and Economics. Volume V. The Economics of Crime and Litigation. BoudEwIJN Bouckaert, Gerrit De Geest (eds.), Cheltenham, Edward Elgar, 2000, p. 350.

Ferrajoli, Luigi. Derecho y razón, $9^{a}$ ed. Perfecto Andrés Ibáñez, Alfonso Ruíz Miguel, Juan Carlos Bayón Mohino, Juan Terradillos Basoco, Rocío Cantarero Bandrés (trads.), Madrid, Trotta, 2009, pp. 490 y 491.

FORST, BRIAN. "Participation in illegitimate activities: further empirical findings", Policy Analysis, Vol. 2, n. . 3, Los Angeles, University of California Press, 1976, p. 477-492. Citado en ERLING EIDE. Ob. cit., p. 358. 
Hulsman, Louk y Bernat de Celis, JACQueline. Sistema penal y seguridad ciudadana: hacia una alternativa, Barcelona, Ariel, 1984, p. 91.

Kelsen, Hans. Teoría pura del Derecho, segunda edición. Moisés Nilve (trad.), Buenos Aires, Eudeba, 1960, pp. 72 y 73.

KIRZNER, IsRAEL. "El significado del proceso de mercado”, Libertas, n. . 27 (octubre 1997), Buenos Aires, ESEADE, 1997, p. 129.

LAINO, NiCOLÁs. "Criminología actuarial y Law \& Economics. Una visión crítica de la Teoría Económica del Crimen”, Cuadernos de Derecho Penal, Vol. 4, Neuquén, Colegio de Abogados y Procuradores de Neuquén. Instituto de Derecho Penal y Procesal Penal, 2007, p. 14.

LeA, John y Young, Jock. ¿Qué hacer con la ley y el orden? Martha Gil y Mariano Ciafardini (trads.), Buenos Aires, Del Puerto, 2001, p. 115.

Méndez Reategui, Rubén. "Conducta delictiva, estados emocionales y disuasión: un enfoque económico”, Jus Doctrina y Práctica, n. ${ }^{\circ}$ 1, Lima, Editora Jurídica Girjley, 2008, p. 121.

Nino, CARlos. Introducción al análisis del Derecho, segunda edición, Buenos Aires, Astrea, 1998, p. 363.

Nozick, Robert. Anarquía, estado y utopía. Rolando Tamayo (trad.), México D.F., Fondo de Cultura Económica, 1988, p. 74.

Posner, Richard. "Utilitarismo, economía y teoría del Derecho", en Estudios Públicos, n. ${ }^{\circ}$ 69, Santiago de Chile, Centro de Estudios Públicos, 1998, p. 234.

Rawls, John. Teoría de la Justicia, segunda edición. María Dolores González (trad.), México DF, Fondo de Cultura Económica, 1995, p. 33.

Rojas, Ricardo Manuel. Las contradicciones del Derecho Penal, Buenos Aires, Ad-Hoc, 2000, p. 71.

RoEMER, Andrés. Introducción al Análisis Económico del Derecho, México D.F., Fondo de Cultura Económica, 1994, p. 7.

Rothbard, Murray. "Hacia una reconstrucción de la utilidad y de la economía del bienestar", Libertas, n. 6 (mayo 1987), Buenos Aires, ESEADE, 1987, p. 223.

ROTHBARD, MURRAY. El hombre, la economía y el estado: un tratado sobre principios de economía. Norberto Sedaca (trad.), Buenos Aires, ESEADE, 2004, p. 29. 
Silva, García Germán. "Una revisión del análisis económico del Derecho: una lectura crítica a propósito de la obra Crimen e Impunidad", Revista de Economía Institucional, n. ${ }^{\circ}$, primer semestre 2000, Bogotá, Universidad Externado de Colombia, 2000, p. 180.

VON HAYEK, FRIEDRICH. "El uso del conocimiento en la sociedad", Estudios Públicos, n. ${ }^{\circ} 12$, Santiago de Chile, Centro de Estudios Públicos,1983, p. 158.

VON HAYEK, FRIEDRICH. Los fundamentos de la libertad, tercera edición. JosÉ VICENTE TORRENTE (trad.), Madrid, Unión Editorial, 1975, p. 203.

VON Mises, Ludwig. La acción humana, octava edición. Joaquín Reig Albiol (trad.), Madrid, Unión Editorial, 2007, p. 55.

Vozmediano, Laura; San Juan, César y Vergara, Ana Isabel. "Problemas de medición del miedo al delito. Algunas respuestas teóricas y técnicas", en Revista Electrónica de Ciencia Penal y Criminología , n. ${ }^{\circ}$ 10-07 (2008), Granada, Universidad de Granada, 2008, p. 5. Disponible en http://criminet.ugr.es/recpc/10/recpc10-07. pdf (visitada el 24/3/2015). 